\title{
Effect of Integrating Chickpea and Organic Amendments on Yield and Quality Attributes of Tomato and Maize in Central Kenya
}

\author{
Ndukhu, O; Onwonga, N; Wahome, G; Kironch, G; Høgh Jensen, Henning
}

Published in:

Journal of Agriculture and Ecology Research International

Link to article, DOI:

10.9734/JAERI/2017/16202

Publication date:

2017

Document Version

Publisher's PDF, also known as Version of record

Link back to DTU Orbit

Citation (APA):

Ndukhu, O., Onwonga, N., Wahome, G., Kironch, G., \& Høgh Jensen, H. (2017). Effect of Integrating Chickpea and Organic Amendments on Yield and Quality Attributes of Tomato and Maize in Central Kenya. Journal of Agriculture and Ecology Research International, 12(4), 1-22. [16202]. https://doi.org/10.9734/JAERI/2017/16202

\section{General rights}

Copyright and moral rights for the publications made accessible in the public portal are retained by the authors and/or other copyright owners and it is a condition of accessing publications that users recognise and abide by the legal requirements associated with these rights.

- Users may download and print one copy of any publication from the public portal for the purpose of private study or research.

- You may not further distribute the material or use it for any profit-making activity or commercial gain

- You may freely distribute the URL identifying the publication in the public portal 


\title{
Effect of Integrating Chickpea and Organic Amendments on Yield and Quality Attributes of Tomato and Maize in Central Kenya
}

\author{
O. H. Ndukhu ${ }^{1^{*}}$, N. R. Onwonga ${ }^{1}$, G. R. Wahome ${ }^{1}$, G. Kironch ${ }^{1}$ \\ and $H$. H. Jensen ${ }^{2}$ \\ ${ }^{1}$ University of Nairobi, Kenya. \\ ${ }^{2}$ Technical University of Denmark, National Food Institute, Denmark.
}

\begin{abstract}
Authors' contributions
This work was carried out in collaboration among all authors. Author OHN contacted literature searches, experimental setup, data analyses and article compilation. The rest formulated the concept and edited the article (academic supervision).

Article Information

DOI: $10.9734 / J A E R I / 2017 / 16202$

Editor(s):

(1) George Tsiamis, Department of Environmental and Natural Resources Management, University of Patras, Greece.

Reviewers:

(1) Frank Oroka, Delta State University, Asaba Campus, Nigeria. (2) Ambati Ravinder Raju, Central Institute for Cotton Research (ICAR), Nagpur, India.

(3) Hab. Takács-györgy Katalin, Károly Róbert College, Hungary. Complete Peer review History: http://www.sciencedomain.org/review-history/20837
\end{abstract}

Original Research Article

Received 15 ${ }^{\text {th }}$ January 2015

Accepted $28^{\text {th }}$ March 2016

Published 6 ${ }^{\text {th }}$ September 2017

\begin{abstract}
A study was carried out to evaluate the effect of integrating chickpea on yield and quality attributes of tomatoes and maize under varying supply levels of farm yard manure (FYM) and phosphate rock (PR). The study was conducted both on-farm (farmer's field in Kiserian, Kajiado County) and onstation at Kabete Campus field station, University of Nairobi, Kenya. The experimental design was a randomized complete block (RCBD) with four replications in a split plot arrangement where the main plots were three cropping systems; monocropping, intercropping and crop rotation and the split plots were FYM and PR. Crop yields, nutrients and physical attributes increased in the different treatments in the following order control $<$ MRP $<$ FYM in the three cropping systems across the four growing seasons at both sites. Tomato in season four in rotations with chickpea at Kabete had; FYM: $3.65 \% \mathrm{~N}, 597 \mathrm{ppm} \mathrm{P}, 3.95 \mathrm{Mg} \mathrm{ha}^{-1}$ fruit yield and $1.554 \mathrm{t} \mathrm{ha}^{-1}$ biomass, firm and $>170 \mathrm{~g}$ and $6 \mathrm{~cm}$. MRP: $3.09 \% \mathrm{~N}, 634 \mathrm{ppm}$ P, $2.907 \mathrm{Mg} \mathrm{ha}^{-1}$ yield and $1.093 \mathrm{t} \mathrm{ha}^{-1}$ biomass, firm and
\end{abstract}


$>100 \mathrm{~g}$ and $3 \mathrm{~cm}$. Control: $2.47 \% \mathrm{~N}, 533 \mathrm{ppm} \mathrm{P}, 2.149 \mathrm{Mg} \mathrm{ha}^{-1}$ fruit yield and $0.757 \mathrm{t} \mathrm{ha}^{-1}$, flaccid and $<100 \mathrm{~g}$ and $3 \mathrm{~cm}$. Monocrop gave; control: $2.17 \% \mathrm{~N}, 494 \mathrm{ppm} \mathrm{P}, 2.138 \mathrm{Mg} \mathrm{ha}^{-1}$ fruit yield and $0.697 \mathrm{t} \mathrm{ha}^{-1}$ biomass. FYM: $3.03 \% \mathrm{~N}, 587 \mathrm{ppm} \mathrm{P}, 3.59 \mathrm{Mg} \mathrm{ha}^{-1}$ fruit yield and $1.523 \mathrm{t} \mathrm{ha}^{-1}$ biomass. MRP: $2.56 \% \mathrm{~N}, 553 \mathrm{ppm} \mathrm{P}, 2.951 \mathrm{Mg} \mathrm{ha}^{-1}$ yield and $1.046 \mathrm{t} \mathrm{ha}^{-1}$ biomass. Similar trends were observed in maize and tomato performances in all the seasons at both sites. Thus it can be deduced that, FYM and MRP application and legume integration in cropping systems improve crop performance.

Keywords: Chickpea; cropping systems; maize; organic inputs; tomato; yield and quality attributes.

\section{INTRODUCTION}

Soil fertility is viewed as an ecosystem concept integrating the diverse soil functions, including nutrient supply, which promote plant production [1]. The complex relationships that exist between different system components and the sustainability of the system is dependent upon the functioning of a whole integrated and interrelated system as recognized in the application of organic farming techniques [2]. The use of organic soil amendments such as farm yard manure and rock phosphate has been associated with desirable soil properties including increased plant available nutrients, water holding capacity and cation exchange capacity and low bulk density besides fostering beneficial microorganisms [3]. Use of rock phosphate, compost and weed teas improve plant growth and optimize fertilizer use efficiency [4]. These soil attributes are enhanced in tomato/maize legume intercrop farming systems [5]. Maize and tomatoes are important (food security) crops in Kenya and are grown under different cropping systems and use of varied organic inputs in their production [6].

Organic farmers practice crop rotations in order to build and maintain soil health, break the lifecycle of pests and suppress the growth of weeds, thus reducing the need for synthetic fertilizer and pesticide applications [7]. Leguminous plants may, due to their ability to fix atmospheric nitrogen, improve soil fertility in both crop rotation and intercropping systems [8].

Intercropping maize and tomatoes with chickpea has been reported to increase light interception in the intercrops, reduce water evaporation, and improve conservation of the soil moisture compared with maize and tomato mono-crops [9].
Maize (corn), soybeans and wheat are three common crops often grown using monocropping techniques. The concentrated presence of a single cultivar, genetically adapted with a single resistance strategy, presents a situation in which an entire crop can be wiped out very quickly by a single opportunistic species [10]. The monocropping system concentrates the labour demand in short time periods during the year and may have greater negative impacts on long-term productivity due to decreasing soil quality due to erosion, loss of organic matter and soil structure [11]).

Maize (Zea mays L.) is a dominant food crop in Kenya [12]. Total maize production and maize yield per unit area in Kenya has been affected by many different factors. Among the most important are total planted area and productivity. There is limited scope for expanding cultivated land under maize production since unused land is diminishing or is of marginal quality or just unsuitable for maize and tomato production [12]. This consequently results in intensification of many crops. Tomatoes (Lycopersicon esculentum L.), are among the most important certified organic food products from Kenya to the international markets where they are grown in almost all households as a staple fruity vegetable [4]. One of the attractions of organic tomato produce is the premium price $(10-30 \%)$ in the marketplace. Fresh market tomatoes require about 35 to $50 \mathrm{~kg}$ of nitrogen (N) per acre. Most, if not all, can be supplied by legumes in rotation and intercrops [10]. The objective of the current study was therefore to investigate the effect on yields of maize and tomato of rock phosphate and farm yard manure on soils with a low fertility. Simultaneously the effect of integrating a grain legume like chickpea on yield maize and tomato was investigated over time (4 cropping seasons) and potential interactions between cropping systems and organic inputs at the study sites. 


\section{MATERIALS AND METHODS}

\subsection{Experimental Design}

The experimental design was a randomized complete block design (RCBD) with split plot arrangement replicated four times. The main plots were cropping systems; monocropping, intercropping and crop rotation and the split plots were organic inputs (FYM and MPR). Each plot measured $4.8 \times 3.75 \mathrm{~m}$. The test crops were; tomato (Lycopersicon esculentum L, variety Rio Grande) and maize (Zea mays L, var.H513), intercropped or in rotation with chickpea.

\subsection{Land Preparation, Planting and Weeding}

The land was prepared manually using hand hoes in late February and September of 2012 and 2013. A nursery was established for tomato seed germination and after 6 weeks, seedlings were transplanted in each season. FYM characterization was done to determine the application rate to supply enough $\mathrm{C}, \mathrm{N}$ and $\mathrm{P}$. Often $10 \mathrm{t} \mathrm{ha}^{-1}$ FYM has been used in several field experiments to supply adequate amounts of $P$ and $N$. Since Minjingu phosphate rock contains $28 \% \mathrm{P}_{2} \mathrm{O}_{5}, 490 \mathrm{~kg} \mathrm{ha}{ }^{-1}$ of it was applied to supply the recommended $60 \mathrm{~kg} \mathrm{P}^{-1}$ to obtain good crop yields. Spacing of $30 \times 75 \mathrm{~cm}$ for maize, 45 x $75 \mathrm{~cm}$ for tomatoes and $10 \times 30 \mathrm{~cm}$ for chickpea pure stands were adopted. Weeding was done at 3 weeks after transplanting and after fruiting. Biopesticides and local plant extracts were used in pests and diseases management. The crops were planted in March and October during the long and short rain seasons of the years 2012 and 2013 and laid out as shown below (Fig. 1).

\subsection{Sampling and Analysis}

Chickpea: Ten plants were randomly selected from each plot and tagged. Pods were harvested and placed in paper bags.
The harvested pods from the sampled plants were shelled and seeds counted for each plant. The average numbers of seeds per plant/plot was obtained. The final grain yield was determined by weighing all the seeds from the sampled plants and converting the yield in kilograms per hectare. Plant height, pods per plant and grain yield were determined on the tagged plants.

Tomatoes: Ten plants per plot were selected for biweekly determination of plant height and number of; flowers, branches, stems and fruits. The number and weight of the fruits was evaluated between 72 and 90 days after transplanting. The physical quality attributes; fruit size (measuring tape), weight (weighing balance), shape, colour (colour chart) and pest and disease attack (presence/absence) were also determined. These attributes were defined as: Extra: uniform colour, good health state, square shape, and weight $>190 \mathrm{~g}$; class l: uniform colour, good health state, non-square shape and weight $>225 \mathrm{~g}$; class II: uniform colour, good health state, non-square shape and weight of 224-170 g; class III: uniform colour, good health state, non-square shape and weight of 100-170 g; non marketable: rotten, have blossom-end rot and lighter than $100 \mathrm{~g}$. The final fruit yield was determined by counting and weighing all the fruits from the sampled plants and converting the yield into mega-grams per hectare. Fruit $\mathrm{N}, \mathrm{P}$ and $\mathrm{K}$ content was determined in the laboratory.

Maize: Ten plants per experimental unit were tagged to provide data at harvest on; number of usable cobs and grain yield of maize. Data were collected on plant; height, stands count/germination, leaves, leaf length and width, number of ears/cobs, and grain $\mathrm{N}, \mathrm{P}$ and $\mathrm{K}$ content. The physical attributes; cob size (measuring tape), shape, weight (weighing balance), grain colour (colour chart) and pest and disease attack (presence/absence) were also

\begin{tabular}{|c|c|c|c|c|c|c|c|c|}
\hline \multicolumn{3}{|c|}{ Monocropping } & \multicolumn{3}{|c|}{ Crop rotation } & \multicolumn{3}{|c|}{ Intercropping } \\
\hline FYM & MPR & Control & MPR & FYM & Control & FYM & MPR & Control \\
\hline \multicolumn{3}{|c|}{ Intercropping } & \multicolumn{3}{|c|}{ Monocropping } & \multicolumn{3}{|c|}{ Crop Rotation } \\
\hline MPR & Control & FYM & FYM & Contro & MPR & Control & FYM & MPR \\
\hline \multicolumn{3}{|c|}{ Crop rotation } & \multicolumn{3}{|c|}{ Monocropping } & \multicolumn{3}{|c|}{ Intercropping } \\
\hline Control & MPR & FYM & Control & FYM & MPR & FYM & Control & MPR \\
\hline \multicolumn{3}{|c|}{ Intercropping } & \multicolumn{3}{|c|}{ Crop rotation } & \multicolumn{3}{|c|}{ Monocropping } \\
\hline FYM & MPR & Control & MPR & FYM & Control & FYM & MPR & Control \\
\hline
\end{tabular}

Fig. 1. Field layout 
observed. The stover/biomass, grain yield $\left(\mathrm{t} \mathrm{ha}{ }^{-1}\right)$ and harvested plant population per hectare were calculated using the relevant variables collected.

Tomato, maize and chickpea tissue samples were collected. Sampling was done at physiological maturity to assess the changes in plant nutrient levels.

Phosphorus: Plant $\mathrm{P}$ was extracted by shaking for 30 minutes at 1:10 ratio with double acid. The Molybdenum Blue method was followed [13].

Organic carbon $(\% \mathrm{C})$ : The organic carbon was estimated by the Walkley-Black method. Recovery factor was used [14].

Total nitrogen $(\% \mathrm{~N})$ : The total nitrogen was estimated by the semi-micro Kjeldahl method [14].

Potassium (K): was determined using flame photometer [15].

\subsection{Statistical Analysis}

Analysis of variance to assess the effects of sites, seasons, cropping systems and organic inputs (farm yard manure and Minjingu phosphate rock) and their interactions on tomato and maize yield and their quality attributes was conducted using GENSTAT $15^{\text {th }}$ Edition [16]. The Least Significant Difference (LSD) test was used to separate means of significant differences among treatment means $(P<0.05)[17]$.

\section{RESULTS AND DISCUSSION}

\subsection{Tomato Growth Characteristics}

Tomato germination, population and flowering increased in the different treatments in the following order control < MRP < FYM in the three cropping systems across the four growing seasons at both sites (Table 1). FYM gave; $92 \%$ germination, $96 \%$ flowering. MRP had; $83 \%$ germination, $92 \%$ flowering. Control gave; $65 \%$ germination, $73 \%$ flowering (Table 1) in the chickpea rotation of the fourth season at Kabete. In the same season, organic inputs in monocrop gave; control: $60.5 \%$ germination, $55 \%$ flowering. FYM: $85 \%$ germination, 93\% flowering. MRP: $73 \%$ germination, $83 \%$ flowering (Table 1) at Kabete. Full results are presented in Table 1).

\subsection{Tomato Nutrient Quality}

Similarly, control gave significantly lower values for fruit $\mathrm{N}$ and $\mathrm{P}$ than FYM and MRP (Table 2).
FYM had; $3.65 \%$ fruit $\mathrm{N}$ and $597 \mathrm{ppm}$ fruit $\mathrm{P}$. MRP had; $3.09 \%$ fruit $\mathrm{N}$ and $634 \mathrm{ppm} \mathrm{P}$. Control had; $2.47 \%$ fruit $\mathrm{N}$ and $533 \mathrm{ppm}$ fruit $\mathrm{P}$ (Table 2) in the chickpea rotation of the fourth season at Kabete. In the same season, organic inputs in monocrop gave; control: $2.17 \%$ fruit $\mathrm{N}$ and 494 ppm fruit P. FYM: $3.03 \%$ fruit $\mathrm{N}$ and $587 \mathrm{ppm}$ fruit P. MRP: $2.56 \%$ fruit $\mathrm{N}$ and $553 \mathrm{ppm}$ fruit $\mathrm{P}$ (Table 2) at Kabete. Full results are presented in Table 2.

From the crop quality viewpoint, the reviewed long-term research showed, for example, that source-separated organic waste compost as well as mixtures of sugar beet vinasse composted with other agro-industrial solid wastes did not adversely affect the quality of products [18]. In particular, winter rye protein concentration was similar in compost and mineral fertilized treatments, and the nitrate concentration of potato tubers in compost treatments was not significantly higher than in the unfertilized control [18]. The crop quality in some cases was even improved by compost fertilization. In one above mentioned study, the partial substitution of mineral with organic $\mathrm{N}$ not only improved the quality of wheat, with respect to mineral fertilizer, but also increased the protein content by $6 \%$ in comparison with the unfertilized control [19].

Therefore, considering that stabilized organic amendment application does not reduce the crop yield quality, as reviewed here, but even enhance their use can appear more profitable. From all the above discussion, there is clear evidence that the best agronomic performance of organic amendments, e.g. farm yard manure and compost, and rock phosphate, is often obtained with both high rates and frequency of applications, leading to residual effects as a slow-release nitrogen fertilizer thus enhanced crop yields. After all, the analyzed soil management practices used in sustainable farming systems have potential for producing comparable yields to conventional farming ones.

The higher $\mathrm{N}$ and $\mathrm{P}$ uptake by maize and tomato in rotations and intercrops could be attributed to higher soil nutrient status as a result of higher biomass addition compared to monocrop plots. Similar results were also reported by [20]. The increased $\mathrm{N}$ and $\mathrm{P}$ uptake by maize and tomato in crop rotations and intercrops could also be due to higher availability of $\mathrm{N}$ and $\mathrm{P}$ on decomposition of the legume. The results are in conformity with the findings of [21]. 
Crop rotation, cover cropping, green manuring, use of livestock manures, and composting are all soil-building practices that do much more than provide nitrogen. By adding organic matter and stimulating biological activity in the soil, these practices make mineral nutrients more available to plants, generate the microbial production of plant-beneficial chemicals (e.g., streptomycin), and improve soil tilth.

The nitrogen reserves in the soil are limited. Chemical fertilizers are expensive and nonrenewable. Hence, renewable biological nitrogen fixation is a very good alternative. Green manure crops ensure ecological sustainability maintaining the productivity of the soil over a long period by protecting soil from erosion. Depending upon the species and locations, green manure crops supply 40 to $120 \mathrm{~kg} \mathrm{~N} \mathrm{ha}^{-1}$ [22].

\subsection{Tomato Yields}

The control without any inputs yielded significantly $(p<0.05) \quad$ lower grain yields compared to the other two input treatments across the two sites in all the growing seasons. FYM gave; $3.95 \mathrm{Mg} \mathrm{ha}^{-1}$ fruit yield and $1.554 \mathrm{t} \mathrm{ha}^{-1}$ biomass. MRP gave; $2.907 \mathrm{Mg} \mathrm{ha}{ }^{-1}$ yield and $1.093 \mathrm{t} \mathrm{ha}^{-1}$ biomass. Control gave; $2.149 \mathrm{Mg} \mathrm{ha}^{-1}$ fruit yield and $0.757 \mathrm{t} \mathrm{ha}^{-1}$ biomass in the chickpea rotation of the fourth season at Kabete (Table 2). In the same season, organic inputs in monocrop gave; control: $2.138 \mathrm{Mg} \mathrm{ha}^{-1}$ fruit yield and $0.697 \mathrm{tha}^{-1}$ biomass. FYM: $3.59 \mathrm{Mg} \mathrm{ha}^{-1}$ fruit yield and $1.523 \mathrm{t} \mathrm{ha}^{-1}$ biomass. MRP: $2.951 \mathrm{Mg}$ $\mathrm{ha}^{-1}$ yield and $1.046 \mathrm{t} \mathrm{ha}^{-1}$ biomass (Table 2) at Kabete.

Table 1. Effects of season, cropping systems and organic inputs on tomato crop development

\begin{tabular}{|c|c|c|c|c|c|c|}
\hline \multirow[t]{2}{*}{ Season } & \multirow[t]{2}{*}{ Cropping system } & \multirow{2}{*}{$\begin{array}{l}\text { Organic } \\
\text { inputs }\end{array}$} & \multicolumn{2}{|c|}{ Kabete } & \multicolumn{2}{|c|}{ Kiserian } \\
\hline & & & $\begin{array}{l}\text { Germination } \\
(\%)\end{array}$ & Flowers (\%) & $\begin{array}{l}\text { Germination } \\
(\%)\end{array}$ & $\begin{array}{l}\text { Flowers } \\
(\%)\end{array}$ \\
\hline \multirow[t]{6}{*}{ I } & Intercrop & CONT & $56^{b}$ & $53^{b}$ & $56^{b}$ & $54^{\text {cd }}$ \\
\hline & & FYM & $81^{\mathrm{klmn}}$ & $93^{\text {ghi }}$ & $82^{h i j k}$ & $92^{k}$ \\
\hline & & MRP & $69^{\text {efghi }}$ & $80^{\mathrm{e}}$ & $71^{\text {ef }}$ & $82^{h}$ \\
\hline & Monocrop & CONT & $61^{\text {bcde }}$ & $56^{\mathrm{bc}}$ & $60^{\mathrm{b}}$ & $50^{\mathrm{b}}$ \\
\hline & & FYM & $86^{\mathrm{mno}}$ & $96^{\mathrm{ij}}$ & $86^{\mathrm{ijkl}}$ & $88^{j}$ \\
\hline & & MRP & $74^{\mathrm{hijkl}}$ & $83^{\mathrm{ef}}$ & $75^{\text {efgh }}$ & $76^{\mathrm{g}}$ \\
\hline \multirow[t]{9}{*}{ II } & Crop rotation & CONT & $65^{\text {defgh }}$ & $70^{\mathrm{d}}$ & $63^{b c}$ & $71^{\mathrm{e}}$ \\
\hline & & FYM & $98^{\mathrm{p}}$ & $94^{\mathrm{hij}}$ & $91^{1}$ & $97^{1}$ \\
\hline & & MRP & $82^{\mathrm{klmn}}$ & $90^{9}$ & $77^{\text {efgh }}$ & $92^{k}$ \\
\hline & Intercrop & CONT & $56^{\mathrm{b}}$ & $53^{\mathrm{b}}$ & $56^{\mathrm{b}}$ & $55^{\mathrm{d}}$ \\
\hline & & FYM & $83^{\operatorname{lmno}}$ & $93^{\text {ghi }}$ & $82^{\mathrm{hij}}$ & $93^{k}$ \\
\hline & & MRP & $69^{\text {efghi }}$ & $80^{\mathrm{e}}$ & $71^{\text {ef }}$ & $83^{h}$ \\
\hline & Monocrop & CONT & $61^{\text {bcdef }}$ & $58^{\mathrm{C}}$ & $61^{\mathrm{b}}$ & $49^{b}$ \\
\hline & & FYM & $90^{\text {nop }}$ & $96^{\mathrm{ij}}$ & $89^{\mathrm{jkl}}$ & $87^{\mathrm{ij}}$ \\
\hline & & MRP & $77^{\mathrm{ijklm}}$ & $86^{f}$ & $78^{\mathrm{fgh}}$ & $75^{\mathrm{fg}}$ \\
\hline \multirow[t]{6}{*}{ III } & Intercrop & CONT & $56^{\mathrm{bcd}}$ & $54^{\mathrm{b}}$ & $60^{\mathrm{b}}$ & $55^{d}$ \\
\hline & & FYM & $83^{\operatorname{lmno}}$ & $94^{\text {ghij }}$ & $81^{\text {ghi }}$ & $95^{\mathrm{kl}}$ \\
\hline & & MRP & $71^{\text {ghij }}$ & $81^{\mathrm{e}}$ & $70^{\mathrm{ce}}$ & $82^{\mathrm{h}}$ \\
\hline & Monocrop & CONT & $61^{\text {bcdef }}$ & $56^{\mathrm{bc}}$ & $62^{\mathrm{b}}$ & $51^{\mathrm{bc}}$ \\
\hline & & FYM & $90^{\text {nop }}$ & $94^{\mathrm{hij}}$ & $90^{\mathrm{kl}}$ & $89^{j}$ \\
\hline & & MRP & $79^{\mathrm{jklm}}$ & $84^{\mathrm{ef}}$ & $77^{\text {efgh }}$ & $77^{g}$ \\
\hline \multirow[t]{11}{*}{ IV } & Crop rotation & CONT & $65^{\text {bdefg }}$ & $73^{d}$ & $63^{\text {bcd }}$ & $72^{\text {ef }}$ \\
\hline & & FYM & $92^{\mathrm{op}}$ & $96^{\mathrm{j}}$ & $91^{\prime}$ & $97^{1}$ \\
\hline & & MRP & $83^{\operatorname{lmno}}$ & $92^{g h}$ & $81^{\text {hi }}$ & $93^{k}$ \\
\hline & Intercrop & CONT & $58^{\text {bcd }}$ & $55^{\mathrm{bc}}$ & $58^{b}$ & $57^{d}$ \\
\hline & & FYM & $83^{\operatorname{lmno}}$ & $93^{\text {ghij }}$ & $87^{\mathrm{ijk} k}$ & $95^{\mathrm{kl}}$ \\
\hline & & MRP & $70^{\text {fghi }}$ & $83^{\text {ef }}$ & $73^{\text {efg }}$ & $85^{\mathrm{hi}}$ \\
\hline & Monocrop & CONT & $61^{\text {bcde }}$ & $55^{\mathrm{bc}}$ & $57^{\mathrm{b}}$ & $51^{\mathrm{bc}}$ \\
\hline & & FYM & $85^{\mathrm{mno}}$ & $93^{\text {ghij }}$ & $90^{\mathrm{kl}}$ & $88^{i j}$ \\
\hline & & MRP & $73^{\text {ghijk }}$ & $83^{\text {ef }}$ & $77^{\text {efgh }}$ & $78^{g}$ \\
\hline & & Mean & 62 & 66 & 61 & 64 \\
\hline & & $\mathrm{LSD}_{0.05}$ & 8 & 3 & 7 & 3 \\
\hline
\end{tabular}

Legend: Cont-control, MRP-Minjingu rock phosphate, FYM-farm yard manure. Means with the same letters within the column are not significantly different $(P<0.05)$. 
Ndukhu et al.; JAERI, 12(4): 1-22, 2017; Article no.JAERI.16202

Table 2. Effects of season, cropping systems and organic inputs on tomato N, P content and yield Attributes during 2012/13 period

\begin{tabular}{|c|c|c|c|c|c|c|c|c|c|c|}
\hline \multirow[t]{2}{*}{ Season } & \multirow[t]{2}{*}{ Cropping system } & \multirow{2}{*}{$\begin{array}{l}\text { Organic } \\
\text { inputs }\end{array}$} & \multicolumn{4}{|c|}{ Kabete } & \multicolumn{4}{|c|}{ Kiserian } \\
\hline & & & $\begin{array}{l}\text { Fruit } \\
\text { N (\%) }\end{array}$ & $\begin{array}{l}\text { Fruit P } \\
\text { (ppm) }\end{array}$ & $\begin{array}{l}\text { Yield } \\
\left(\text { Mgha }^{-1}\right)\end{array}$ & $\begin{array}{l}\text { Biomass } \\
\left(\mathrm{t} \mathrm{ha}^{-1}\right)\end{array}$ & $\begin{array}{l}\text { Fruit } \\
\text { N (\%) }\end{array}$ & Fruit $P(p m)$ & $\begin{array}{l}\text { Yield } \\
\left(\text { Mgha }^{-1}\right)\end{array}$ & $\begin{array}{l}\text { Biomass } \\
\left(\mathrm{t} \mathrm{ha}^{-1}\right)\end{array}$ \\
\hline \multirow[t]{6}{*}{ I } & Intercrop & CONT & $1.9^{\mathrm{b}}$ & $506^{\mathrm{d}}$ & $1.9^{\mathrm{b}}$ & $0.65^{\mathrm{b}}$ & $2.2^{\mathrm{et}}$ & $488^{\mathrm{C}}$ & $1.9^{\mathrm{C}}$ & $0.61^{\mathrm{b}}$ \\
\hline & & FYM & $3.6^{\mathrm{s}}$ & $603^{1}$ & $3.6^{\operatorname{lm}}$ & $1.39^{\circ}$ & $3.3^{q}$ & $551^{\mathrm{h}}$ & $3.5^{\mathrm{m}}$ & $1.33^{\circ}$ \\
\hline & & MRP & $2.6^{\text {ghij }}$ & $570^{i}$ & $2.6^{\mathrm{e}}$ & $0.92^{i}$ & $2.7^{1 \mathrm{mn}}$ & $592^{k}$ & $2.6^{\text {et }}$ & $0.87^{i}$ \\
\hline & Monocrop & CONT & $2.0^{\mathrm{bc}}$ & $481^{\mathrm{b}}$ & $2.0^{\mathrm{C}}$ & $0.70^{\dagger}$ & $1.9^{b c}$ & $478^{b}$ & $1.9^{c}$ & $0.66^{\dagger}$ \\
\hline & & FYM & $3.3^{p q}$ & $541^{g}$ & $3.8^{n}$ & $1.52^{t}$ & $3.7^{\mathrm{q}}$ & $539^{9}$ & $3.2^{\mathrm{j}}$ & $1.45^{\mathrm{t}}$ \\
\hline & & MRP & $2.8^{\mathrm{ijkl}}$ & $573^{i}$ & $2.8^{\mathrm{fg}}$ & $1.05^{\prime}$ & $2.6^{\mathrm{kl}}$ & $570^{i}$ & $2.6^{\mathrm{fg}}$ & $0.99^{\prime}$ \\
\hline \multirow[t]{9}{*}{ II } & Crop rotation & CONT & $2.6^{\text {tghi }}$ & $529^{\dagger}$ & $2.0^{c}$ & $0.75^{\mathrm{g}}$ & $1.8^{\mathrm{b}}$ & $530^{\dagger}$ & $1.9^{c}$ & $0.71^{9}$ \\
\hline & & FYM & $3.6^{\mathrm{rs}}$ & $642^{p}$ & $3.9^{\text {no }}$ & $1.53^{\mathrm{u}}$ & $3.5^{r}$ & $594^{k}$ & $3.7^{\text {no }}$ & $1.46^{\mathrm{u}}$ \\
\hline & & MRP & $2.9^{\mathrm{mn}}$ & $598^{k}$ & $2.8^{g h}$ & $1.08^{\mathrm{m}}$ & $2.5^{\mathrm{jk}}$ & $630^{\circ}$ & $2.7^{\mathrm{gh}}$ & $1.03^{\mathrm{m}}$ \\
\hline & Intercrop & CONT & $2.3^{\text {de }}$ & $519^{e}$ & $2.0^{\mathrm{c}}$ & $0.65^{\mathrm{bc}}$ & $2.4^{\text {hij }}$ & $504^{d}$ & $2.0^{\mathrm{d}}$ & $0.62^{\mathrm{bc}}$ \\
\hline & & FYM & $3.4^{q r}$ & $618^{m}$ & $3.3^{j}$ & $1.40^{\mathrm{p}}$ & $3.2^{q}$ & $567^{i}$ & $3.3^{\mathrm{k}}$ & $1.33^{p}$ \\
\hline & & MRP & $2.9^{\mathrm{klm}}$ & $584^{\prime}$ & $2.8^{\operatorname{tg}}$ & $0.92^{\prime}$ & $2.8^{\text {no }}$ & $600^{\prime}$ & $2.8^{\mathrm{hl}}$ & $0.88^{\prime}$ \\
\hline & Monocrop & CONT & $2.0^{\mathrm{bc}}$ & $481^{\mathrm{b}}$ & $2.0^{\mathrm{C}}$ & $0.69^{\mathrm{e}}$ & $1.9^{\text {bcd }}$ & $478^{\mathrm{b}}$ & $1.9^{\mathrm{c}}$ & $0.65^{e}$ \\
\hline & & FYM & $2.8^{\mathrm{jklm}}$ & $541^{9}$ & $3.7^{\mathrm{m}}$ & $1.50^{r}$ & $2.7^{1 \mathrm{~m}}$ & $539^{9}$ & $3.2^{\mathrm{j}}$ & $1.43^{r}$ \\
\hline & & MRP & $2.4^{\text {ef }}$ & $573^{i}$ & $2.7^{\text {ef }}$ & $1.03^{k}$ & $2.3^{\operatorname{tgh}}$ & $570^{i}$ & $2.6^{\operatorname{tg}}$ & $1.00^{k}$ \\
\hline \multirow[t]{6}{*}{ III } & Intercrop & CONT & $2.4^{\mathrm{efg}}$ & $516^{\mathrm{e}}$ & $2.0^{c}$ & $0.65^{d}$ & $2.3^{\text {tghi }}$ & $516^{\mathrm{e}}$ & $1.9^{\mathrm{c}}$ & $0.62^{c}$ \\
\hline & & FYM & $3.2^{\mathrm{op}}$ & $583^{j}$ & $3.3^{j}$ & $1.41^{q}$ & $3.4^{r}$ & $581^{\mathrm{j}}$ & $3.6^{n}$ & $1.34^{q}$ \\
\hline & & MRP & $2.7^{\text {hijk }}$ & $626^{n}$ & $2.8^{\text {tg }}$ & $0.93^{\prime}$ & $2.9^{\text {nop }}$ & $615^{m}$ & $2.6^{\text {tg }}$ & $0.88^{\prime}$ \\
\hline & Monocrop & CONT & $2.1^{\mathrm{cd}}$ & $490^{c}$ & $2.1^{\mathrm{d}}$ & $0.69^{e}$ & $2.0^{\mathrm{cd}}$ & $491^{\mathrm{C}}$ & $1.8^{\mathrm{b}}$ & $0.66^{\mathrm{e}}$ \\
\hline & & FYM & $3.0^{\mathrm{mno}}$ & $595^{\mathrm{k}}$ & $3.5^{\mathrm{k}}$ & $1.51^{\mathrm{s}}$ & $2.8^{\mathrm{mno}}$ & $550^{\text {h }}$ & $3.5^{\mathrm{Im}}$ & $1.44^{\mathrm{s}}$ \\
\hline & & MRP & $2.5^{\mathrm{etgh}}$ & $554^{\mathrm{h}}$ & $2.9^{\mathrm{hi}}$ & $1.04^{\mathrm{k}}$ & $2.4^{\mathrm{hij}}$ & $584^{j}$ & $2.5^{\mathrm{e}}$ & $0.99^{k}$ \\
\hline \multirow[t]{11}{*}{ IV } & Crop rotation & CONT & $2.5^{\text {efgh }}$ & $533^{f}$ & $2.2^{\mathrm{d}}$ & $0.76^{\mathrm{h}}$ & $2.2^{\mathrm{fg}}$ & $526^{\dagger}$ & $2.0^{\mathrm{d}}$ & $0.72^{h}$ \\
\hline & & FYM & $3.7^{\mathrm{s}}$ & $597^{k}$ & $4.0^{\circ}$ & $1.55^{v}$ & $3.0^{p}$ & $595^{\mathrm{k}}$ & $3.8^{\circ}$ & $1.48^{v}$ \\
\hline & & MRP & $3.1^{\text {no }}$ & $634^{\circ}$ & $2.9^{\text {hi }}$ & $1.09^{n}$ & $2.6^{\mathrm{kl}}$ & $638^{p}$ & $2.8^{\text {hi }}$ & $1.04^{n}$ \\
\hline & Intercrop & CONT & $2.5^{\mathrm{efgh}}$ & $490^{\mathrm{C}}$ & $1.9^{b}$ & $0.65^{c}$ & $2.4^{\text {ghi }}$ & $513^{\mathrm{e}}$ & $2.0^{\mathrm{d}}$ & $0.62^{d}$ \\
\hline & & FYM & $3.4^{\mathrm{qr}}$ & $595^{k}$ & $3.6^{\operatorname{lm}}$ & $1.41^{q}$ & $3.5^{r}$ & $580^{\mathrm{j}}$ & $3.4^{\mathrm{kl}}$ & $1.34^{q}$ \\
\hline & & MRP & $3.0^{\mathrm{mno}}$ & $554^{\mathrm{h}}$ & $2.6^{\mathrm{e}}$ & $0.93^{j}$ & $2.9^{o p}$ & $623^{n}$ & $2.8^{i}$ & $0.88^{j}$ \\
\hline & Monocrop & CONT & $2.2^{\text {cd }}$ & $494^{\mathrm{c}}$ & $2.1^{\mathrm{d}}$ & $0.70^{\dagger}$ & $2.1^{\text {de }}$ & $488^{\mathrm{c}}$ & $1.8^{\mathrm{b}}$ & $0.66^{\dagger}$ \\
\hline & & FYM & $3.03^{\mathrm{mno}}$ & 587 & $3.6^{\mathrm{kl}}$ & $1.52^{\mathrm{t}}$ & $2.9^{\mathrm{op}}$ & $551^{\mathrm{h}}$ & $3.5^{\operatorname{lm}}$ & $1.45^{t}$ \\
\hline & & MRP & $2.6^{\mathrm{fghi}}$ & $553^{h}$ & $3.0^{i}$ & $1.05^{\prime}$ & $2.4^{\mathrm{ij}}$ & $592^{k}$ & $2.5^{\mathrm{e}}$ & $0.99^{\prime}$ \\
\hline & & Mean & 2.0 & 465 & 2.3 & 0.88 & 2.2 & 463 & 2.2 & 0.84 \\
\hline & & $\mathrm{LSD}_{0.05}$ & 0.2 & 5 & 0.1 & 0.01 & 0.1 & 5 & 0.1 & 0.01 \\
\hline
\end{tabular}

MRP-Minjingu rock phosphate, FYM-farm yard manure. Means with same letters within column are not significantly different $(P \leq 0.05)$. 
The control plots gave lowest yields, probably because of reduced nitrification rates and fixation of $\mathrm{P}$ in the soil that rendered $\mathrm{N}$ and $\mathrm{P}$ unavailable hence limited uptake by the tomato plants and consequently poor performance. Interactions involving manure and crop rotation gave high grain yields. This underlines the importance of FYM and legume integrations in crop performance.

The grain/fruit yield decreased due to competition of maize/tomato and intercropped chickpea for nutrients and moisture. The results were in conformity with the findings of [23,24], who noticed reduction in maize yield when intercropped with different legumes. All the crop parameters were significantly higher in crop rotation and sole maize when compared to intercropped situation. The improvement in yield components of sole maize and rotations could be related to the increased total dry matter production. Maize/tomato intercropped with chickpea resulted in relatively higher $\mathrm{N}$ uptake as compared to sole maize/tomato. This might be due to higher $\mathrm{N}$ availability as a result of decomposition of this legume [25]. Maize/tomato intercropped and rotated with chickpea recorded relatively higher $\mathrm{P}$ uptake than the sole maize/tomato. Growing of chickpea helped in significant uptake of nutrients by maize and tomato, which may be attributed to improved soil structure, which in turn enhanced the nutrient efficiency as observed by [26]. The results are also in conformity with the findings of [25]. The higher per hectare yields of maize and tomato were recorded in sole and rotations than the maize and tomato intercropped with chickpea. This was mainly due to the lack of competition for resources by chickpea with maize and tomato crops. Thus, overall perusal of maize grain and tomato fruit yield data reveals lower performance of maize and tomato in the intercrops than sole crops and rotations as competition offered by chickpea was substantial to lower the yields significantly. The grain yield decreased in the intercrops due to the competition exhibited by intercropped chickpea with maize and tomato for nutrients and moisture. The results were in agreement with the findings of [24], who reported that intercropping of leguminous green manure crops reduced maize yield. Similarly [27] revealed that in corn with annual legume intercropping under weed free conditions, corn grain yield were reduced by the presence of legume in some treatments, while others were comparable to the check yields.

\subsection{Tomato Fruit Physical Quality Attributes}

The tomato fruit physical quality attributes i.e. colour, shape, texture, weight, pest and disease attack and size were differently affected by cropping systems and organic inputs. Farm yard manure and Minjingu rock phosphate consistently produced tomato fruits with red colour, firm texture, oval shape, greater than 170 $\mathrm{g}$ and more than $6 \mathrm{~cm}$ sized fruits in all the cropping seasons in the four growing seasons at both sites as compared to control (Table 3 ).

Consumers take product appearance into consideration as a primary criterion [28]. Colour has been considered to have a key role in food choice, food preference and acceptability, and may even influence taste threshold, sweetness perception and pleasantness [29].

Colour is one of the main attributes, along with texture, that characterises the freshness of most vegetables. Tomato and other vegetables can undergo changes in colour due to different biochemical processes, mainly chlorophyll degradation [30]. Browning and darkening of fresh fruit and vegetables reduces quality [31] and is often the factor limiting shelf-life and marketability of fresh vegetables [32]. Minimally processed vegetables that maintain firm crunchy texture are highly desirable because consumers associate these textures with freshness and wholesomeness [33]. Indeed, the appearance of a soft or limp product may give rise to consumer rejection prior to consumption. Textural changes in vegetables are related to certain enzymatic and non-enzymatic processes.

A number of recent reviews have been published on the effects of organic production systems on produce quality [34].

Reported benefits of produce from organic systems include: higher dry matter content, higher mineral concentrations, lower nitrate $\left(\mathrm{NO}_{3}\right)$ concentrations, higher vitamin $\mathrm{C}$ concentrations, higher phytonutrient content, and better taste.

Of the organic constituents measured in plant tissue, ascorbic acid (vitamin C) has frequently been reported, on average, to be higher in organically grown plants than with plants grown conventionally [35]. Ascorbic acid content of the tomato fruit was significantly lower in the 4:1 $\mathrm{NO}_{3} / \mathrm{NH}_{4}$ treatment than with the 1:4 $\mathrm{NO}_{3} / \mathrm{NH}_{4}$ 
treatments or the organic treatments. One hypothesis for $\mathrm{N}$ source effects suggested by [36] is that the higher $\mathrm{N}$ with inorganic sources increased vegetative growth and caused more shading of fruit, thereby lowering the ascorbic acid content [37]. Interest in other plant secondary compounds has increased because of their potential effects on improving human health [37]. For example, phenolic compounds, which play a role in plant defence mechanisms to resist diseases and insects, also act as antioxidants if consumed in food. Higher levels of phenolic compounds frequently have been reported in organically grown crops than in conventionally grown crops [38].

The role of organic nutrient sources in production of plant phenolic compounds is now unclear, but current evidence suggests that factors other than nutrition may be primarily involved. Results reported by [39] with leafy vegetable crops have shown that the organic systems sometimes provide an opportunity for insect attack, which can result in a higher level of phenolic compounds. In the study discussed by [36] in which ascorbic acid content in tomatoes was lowest in plants receiving $\mathrm{NO}_{3}$ as the dominant $\mathrm{N}$ form, there was no difference in soluble phenolics resulting from treatment, and lycopene was higher in $\mathrm{NO}_{3}$-fed plants than with plants provided with organic nutrient sources. This study was conducted in the greenhouse and was not a comparison of organic systems. Therefore, pest control would have been uniform for the study. A recent study by [40] found that phenolic compounds in lettuce were not consistently affected by nutrient source. In that study, numerous factors, including growing environment, season, and cultivar, affected phenolic compounds with cultivar differences being most significant.

Table 3. Effect of season, cropping systems and organic inputs on physical quality attributes of tomato fruits

\begin{tabular}{|c|c|c|c|c|c|c|c|c|c|}
\hline Season & CS & Input & Colour & Shape & $\begin{array}{l}\text { Weight } \\
\text { (g) }\end{array}$ & $\begin{array}{l}\text { pest \& } \\
\text { disease }\end{array}$ & $\begin{array}{l}\text { Size } \\
(\mathrm{cm})\end{array}$ & Texture & Class \\
\hline \multirow[t]{6}{*}{ I } & IC & CONT & red & oval & $<100$ & $+/+$ & $<3$ & flaccid & III \\
\hline & & FYM & red & oval & $170-224$ & - & $>6$ & firm & I \\
\hline & & MRP & red & oval & $100-170$ & +- & $3-6$ & flaccid & II \\
\hline & MC & CONT & dark-red & irregular & $<100$ & $+/+$ & $<3$ & flaccid & III \\
\hline & & FYM & red & oval & $>190$ & - & $>6$ & firm & 1 \\
\hline & & MRP & red & oval & $100-170$ & - & $3-6$ & firm & II \\
\hline \multirow[t]{9}{*}{ II } & CR & CONT & dark-red & irregular & $<100$ & + & $<3$ & flaccid & III \\
\hline & & FYM & red & oval & $>190$ & - & $>6$ & firm & I \\
\hline & & MRP & red & oval & $100-170$ & - & $3-6$ & firm & II \\
\hline & IC & CONT & dark-red & irregular & $<100$ & + & $<3$ & flaccid & III \\
\hline & & FYM & red & oval & $>190$ & - & $>6$ & firm & I \\
\hline & & MRP & red & oval & $100-170$ & - & $3-6$ & firm & II \\
\hline & MC & CONT & dark-red & irregular & $<100$ & $+/+$ & $<3$ & flaccid & III \\
\hline & & FYM & red & oval & $>190$ & - & $>6$ & firm & I \\
\hline & & MRP & red & oval & $100-170$ & +- & $3-6$ & firm & II \\
\hline \multirow[t]{6}{*}{ III } & IC & CONT & dark-red & irregular & $<100$ & + & $<3$ & flaccid & III \\
\hline & & FYM & red & oval & $>225$ & - & $>6$ & firm & 1 \\
\hline & & MRP & red & oval & $170-224$ & - & $3-6$ & firm & II \\
\hline & MC & CONT & dark-red & irregular & $<100$ & + & $<3$ & flaccid & III \\
\hline & & FYM & red & oval & $>225$ & - & $>6$ & firm & I \\
\hline & & MRP & red & oval & $170-224$ & - & $3-6$ & firm & II \\
\hline \multirow[t]{9}{*}{ IV } & CR & CONT & dark-red & oval & $<100$ & + & $<3$ & flaccid & III \\
\hline & & FYM & red & oval & $>225$ & - & $>6$ & firm & I \\
\hline & & MRP & red & oval & $170-224$ & - & $3-6$ & firm & II \\
\hline & IC & CONT & dark-red & irregular & $<100$ & + & $<3$ & flaccid & III \\
\hline & & FYM & red & oval & $>225$ & - & $>6$ & firm & I \\
\hline & & MRP & red & oval & $170-224$ & - & $3-6$ & firm & ॥ \\
\hline & MC & CONT & dark-red & irregular & $<100$ & $+/+$ & $<3$ & flaccid & III \\
\hline & & FYM & red & oval & $>225$ & - & $>6$ & firm & I \\
\hline & & MRP & red & oval & $170-224$ & +- & $3-6$ & firm & II \\
\hline
\end{tabular}


Using tomatoes grown with various $\mathrm{NO}_{3}: \mathrm{NH}_{4}$ ratios and organic treatments as described for ascorbic acid differences, [41] found that those grown with higher $\mathrm{NH}_{4}$ nutrition and organic nutrient sources rated higher in taste tests than those grown primarily with $\mathrm{NO}_{3}$ nutrition. Analysis by [36] revealed that tomatoes from plants grown with $\mathrm{NO}_{3}$ as the primary $\mathrm{N}$ form had lower titratable acidity and higher $\mathrm{pH}$ than those grown with organic $\mathrm{N}$ sources or $\mathrm{NH}_{4}-\mathrm{N}$ forms. Based on the available literature to date, the taste of produce is affected by many factors sometimes favoured by organic production systems.

Careful management of manure or legumes in organic cropping systems reduced $\mathrm{NO}_{3}$ losses than with conventionally fertilized systems [42]. In that study, over 10 years of cropping using low $\mathrm{C}$ : $\mathrm{N}$ organic residues (manure or legumes) combined with a more diverse cropping system resulted in $30 \%$ lower $\mathrm{N}$ losses compared with a conventionally fertilized corn/soybean system. Over the same time period, average yields and profitability of the organic system were reported to be comparable with the conventional system. These results show that it is possible to maintain soil fertility and yields in an organic system with careful management while reducing $\mathrm{N}$ losses.

Colour is probably the first quality factor judged by tomato product consumers. Thus, an attractive deep red colour is a major quality attribute for tomato products [43].

Gennaro and Quaglia [44] presented extensive data showing a recurrently higher average vitamin $\mathrm{C}$ contents in organic vegetables and physical qualities (especially tomatoes, lettuce, spinach and cabbage), and weak trends indicating higher amounts of some nutritionally significant mineral in organic compared to conventional crops. This adds to the observed non significant trends showing less protein but of a better quality and a higher content of nutritionally significant minerals with lower amounts of some heavy metals in organic crops compared to conventional ones [45].

\subsection{Maize Crop Performance}

Throughout the four growing seasons at both sites, the control treatment, no organic input, performed significantly $(p<0.05)$ lower compared to the other two treatments in all the three cropping systems in maize plots. Maize germination, height and branches increased in the different treatments in the following order control < MRP < FYM in the three cropping systems across the four growing seasons. FYM gave; $96 \%$ germination, $128.8 \mathrm{~cm}$ plant height and 15 leaves. MRP had; $94.9 \%$ germination, $117.8 \mathrm{~cm}$ plant height and 13 leaves. Control gave; $77.8 \%$ germination, $80.3 \mathrm{~cm}$ plant height and 10 leaves (Table 4 ) in maize under chickpea rotation of the fourth season at Kabete. Full results are presented in Table 4.

\subsection{Maize Crop Nutrient Quality}

In terms of grain nutrient contents, control presented significantly $(p<0.05)$ lower values compared to the inputs in all the cropping systems across the growing seasons at both sites. FYM gave; $1.68 \%$ grain $\mathrm{N}$ and 1666 ppm grain P. MRP had; $1.39 \%$ grain $\mathrm{N}$ and 1921 ppm grain $\mathrm{P}$. Control gave; $1.288 \%$ grain $\mathrm{N}$ and 1571 ppm grain $P$, (Table 5) in maize under chickpea rotation of the fourth season at Kabete. Full results are presented in Table 5.

\subsection{Maize Yields}

Control gave significantly lower values of biomass and yield than FYM and MRP. FYM gave; $3.78 \mathrm{t} \mathrm{ha}^{-1}$ grain yield and $6.23 \mathrm{t} \mathrm{ha}^{-1}$ biomass while MRP had; $3.334 \mathrm{t} \mathrm{ha}^{-1}$ grain and $4.38 \mathrm{t} \mathrm{ha}^{-1}$ biomass in maize with chickpea rotation fourth season at Kabete (Table 5). Control gave; $1.63 \mathrm{t} \mathrm{ha}^{-1}$ grain yield and $3.03 \mathrm{t}$ ha $^{-1}$ biomass (Table 5 ) in maize under chickpea rotation of the fourth season at Kabete. Complete results are shown in Table 5.

Lathwell [46] reported that planting crops such as maize immediately following the incorporation of a legume green manure such as chickpea, was a satisfactory practice and if properly managed legume green manures have the potential to meet much, if not all the $\mathrm{N}$ requirement of the succeeding non-legume crop. [47] reported that nitrogen fixed by the legume crop not only meets its own $\mathrm{N}$ requirement but also a sizeable quantity $(30-90 \mathrm{~kg} / \mathrm{ha} N)$ is left for the succeeding crop. In maize based cropping systems, contribution of legumes towards $\mathrm{N}$ contribution was equivalent to $13-67.5 \mathrm{~kg}$ per ha applied to rice succeeding maize fodder ([48]. [49] reported that use of Mucuna (Mucuna pruriens L.) and pigeon pea (Cajanus cajan L.) after maize in the first year reduced $N$ and $P$ fertilizer need in the subsequent year. 
Ndukhu et al.; JAERI, 12(4): 1-22, 2017; Article no.JAERI.16202

Table 4. Effects of seasons, cropping systems and organic inputs on maize development

\begin{tabular}{|c|c|c|c|c|c|c|c|c|}
\hline Season & $\begin{array}{l}\text { Cropping } \\
\text { system }\end{array}$ & Organic inputs & $\begin{array}{l}\text { Germination } \\
(\%)\end{array}$ & Height (cm) & Leaves (No) & Germination (\%) & Height (cm) & $\begin{array}{l}\text { Leaves } \\
\text { (No) }\end{array}$ \\
\hline \multirow[t]{6}{*}{ I } & Intercrop & CONT & $64^{b}$ & $70^{\mathrm{bc}}$ & $7^{\mathrm{bc}}$ & $74^{\mathrm{b}}$ & $67^{\mathrm{bc}}$ & $6^{b}$ \\
\hline & & FYM & $84^{\text {efghi }}$ & $118^{i}$ & $11^{\text {fgh }}$ & $95^{\mathrm{efg}}$ & $114^{i}$ & $11^{\mathrm{klmn}}$ \\
\hline & & MRP & $79^{\text {defg }}$ & $102^{\mathrm{fg}}$ & $10^{e}$ & $90^{\mathrm{e}}$ & $99^{\dagger}$ & $8^{\text {cdetghi }}$ \\
\hline & Monocrop & CONT & $69^{\mathrm{bc}}$ & $72^{\mathrm{bcd}}$ & $8^{\mathrm{cd}}$ & $80^{\text {bcd }}$ & $70^{\text {bcd }}$ & $8^{\text {cdefg }}$ \\
\hline & & FYM & $86^{\text {fghij }}$ & $127^{j}$ & $13^{\mathrm{ij}}$ & $97^{\mathrm{fg}}$ & $125^{\mathrm{j}}$ & $11^{\mathrm{mn}}$ \\
\hline & & MRP & $87^{\text {ghijk }}$ & $106^{\mathrm{gh}}$ & $11^{\text {efg }}$ & $92^{\text {ef }}$ & $104^{\mathrm{gh}}$ & $9^{g h i j k}$ \\
\hline \multirow[t]{9}{*}{ II } & Crop rotation & CONT & $76^{\text {cde }}$ & $77^{\mathrm{de}}$ & $10^{\text {ef }}$ & $84^{d}$ & $75^{\mathrm{de}}$ & $9^{\text {efghijk }}$ \\
\hline & & FYM & $95^{\mathrm{k}}$ & $125^{j}$ & $15^{\mathrm{k}}$ & $98^{\mathrm{fg}}$ & $123^{j}$ & $13^{o p}$ \\
\hline & & MRP & $95^{\mathrm{k}}$ & $114^{\prime}$ & $12^{\mathrm{nt}}$ & $95^{\text {etg }}$ & $112^{\prime}$ & $11^{\mathrm{Imn}}$ \\
\hline & Intercrop & CONT & $65^{\mathrm{b}}$ & $69^{b}$ & $7^{b}$ & $75^{\mathrm{bc}}$ & $67^{b}$ & $6^{\mathrm{bc}}$ \\
\hline & & FYM & $86^{\text {tghij }}$ & $116^{i}$ & $12^{\mathrm{ghi}}$ & $96^{\text {efg }}$ & $114^{i}$ & $11^{\mathrm{mn}}$ \\
\hline & & MRP & $81^{\text {efgh }}$ & $100^{\dagger}$ & $9^{\mathrm{de}}$ & $92^{\text {ef }}$ & $98^{\dagger}$ & $8^{\text {detghij }}$ \\
\hline & Monocrop & CONT & $72^{\mathrm{bcd}}$ & $71^{\mathrm{bc}}$ & $10^{e}$ & $81^{\mathrm{cd}}$ & $69^{\mathrm{bc}}$ & $7^{\text {bcde }}$ \\
\hline & & FYM & $92^{i j k}$ & $125^{\mathrm{j}}$ & $15^{\mathrm{k}}$ & $98^{\mathrm{fg}}$ & $123^{j}$ & $12^{\text {nop }}$ \\
\hline & & MRP & $90^{\text {hijk }}$ & $105^{\text {fgh }}$ & $12^{\mathrm{hi}}$ & $95^{\mathrm{efg}}$ & $103^{\text {fgh }}$ & $10^{\mathrm{jklm}}$ \\
\hline \multirow[t]{6}{*}{ III } & Intercrop & CONT & $65^{\mathrm{b}}$ & $69^{b c}$ & $7^{\mathrm{bc}}$ & $76^{\mathrm{bc}}$ & $68^{\mathrm{bc}}$ & $7^{\mathrm{bcd}}$ \\
\hline & & FYM & $88^{\text {ghijk }}$ & $116^{i}$ & $13^{\mathrm{hi}}$ & $96^{\text {etg }}$ & $116^{i}$ & $12^{\mathrm{mn}}$ \\
\hline & & MRP & $81^{\text {etgh }}$ & $101^{\dagger}$ & $10^{\mathrm{e}}$ & $92^{\mathrm{et}}$ & $100^{\mathrm{tg}}$ & $9^{\text {ghijk }}$ \\
\hline & Monocrop & CONT & $69^{b c}$ & $72^{\mathrm{bc}}$ & $8^{\mathrm{cd}}$ & $84^{d}$ & $70^{\mathrm{bc}}$ & $8^{\text {cdetgh }}$ \\
\hline & & FYM & $94^{\mathrm{jk}}$ & $126^{j}$ & $13^{\mathrm{ij}}$ & $97^{\mathrm{efg}}$ & $124^{j}$ & $12^{\text {no }}$ \\
\hline & & MRP & $85^{\text {fghi }}$ & $105^{\text {fgh }}$ & $10^{\text {ef }}$ & $90^{\mathrm{e}}$ & $103^{\text {fgh }}$ & $10^{\mathrm{ijkl}}$ \\
\hline \multirow[t]{11}{*}{ IV } & Crop rotation & CONT & $78^{\text {det }}$ & $80^{e}$ & $10^{e}$ & $82^{\mathrm{cd}}$ & $78^{\mathrm{e}}$ & $9^{\operatorname{tgh} u k}$ \\
\hline & & FYM & $96^{\mathrm{k}}$ & $129^{j}$ & $14^{\mathrm{jk}}$ & $100^{g}$ & $127^{j}$ & $14^{p}$ \\
\hline & & MRP & $95^{\mathrm{k}}$ & $118^{i}$ & $13^{\mathrm{hi}}$ & $96^{\text {efg }}$ & $116^{\prime}$ & $11^{\mathrm{Imn}}$ \\
\hline & Intercrop & CONT & $66^{\mathrm{b}}$ & $72^{\mathrm{bcd}}$ & $7^{\mathrm{bc}}$ & $77^{\mathrm{bc}}$ & $70^{\mathrm{bcd}}$ & $7^{\text {cdef }}$ \\
\hline & & FYM & $88^{\text {ghijk }}$ & $119^{i}$ & $12^{\mathrm{hi}}$ & $96^{\text {efg }}$ & $117^{i}$ & $12^{\text {no }}$ \\
\hline & & MRP & $82^{\text {efgh }}$ & $104^{\text {fgh }}$ & $10^{\mathrm{e}}$ & $93^{\text {ef }}$ & $102^{\text {fgh }}$ & $9^{g h i j k}$ \\
\hline & Monocrop & CONT & $68^{\mathrm{bc}}$ & $75^{\mathrm{cd}}$ & $8^{\mathrm{bc}}$ & $79^{\mathrm{bcd}}$ & $73^{\mathrm{cd}}$ & $7^{\text {cdet }}$ \\
\hline & & FYM & $95^{\mathrm{k}}$ & $129^{\prime}$ & $13^{\text {hi }}$ & $100^{g}$ & $127^{j}$ & $12^{\text {no }}$ \\
\hline & & MRP & $84^{\text {etghi }}$ & $108^{\mathrm{h}}$ & $10^{\mathrm{e}}$ & $93^{\text {et }}$ & $106^{\mathrm{h}}$ & $9^{9 j \mathrm{jk}}$ \\
\hline & & Mean & 68.1 & 83.9 & 8.8 & 74.8 & 82.2 & 8.0 \\
\hline & & $\mathrm{LSD}_{0.05}$ & 7.30 & 4.6 & 1.2 & 5.6 & 4.6 & 1.5 \\
\hline
\end{tabular}


Ndukhu et al.; JAERI, 12(4): 1-22, 2017; Article no.JAERI.16202

Table 5. Effects of season, cropping systems and organic inputs on maize grain N, P content, yield and biomass

\begin{tabular}{|c|c|c|c|c|c|c|c|c|c|c|}
\hline \multirow[t]{2}{*}{ Season } & \multirow{2}{*}{$\begin{array}{l}\text { Cropping } \\
\text { system }\end{array}$} & \multirow{2}{*}{$\begin{array}{l}\text { Organic } \\
\text { inputs }\end{array}$} & \multicolumn{4}{|c|}{ Kabete } & \multicolumn{4}{|c|}{ Kiserian } \\
\hline & & & $\begin{array}{l}\text { Grain } \\
\text { N (\%) }\end{array}$ & $\begin{array}{l}\text { Grain P } \\
(\mathrm{ppm})\end{array}$ & $\begin{array}{l}\text { Yield } \\
\left(\mathrm{t} \mathrm{ha}^{-1}\right)\end{array}$ & $\begin{array}{l}\text { Biomass } \\
\left(\mathrm{t} \mathrm{ha}^{-1}\right)\end{array}$ & $\begin{array}{l}\text { Grain } \\
\text { N (\%) }\end{array}$ & $\begin{array}{l}\text { Grain P } \\
\text { (ppm) }\end{array}$ & $\begin{array}{l}\text { Yield } \\
\left(t \text { ha }^{-1}\right)\end{array}$ & $\begin{array}{l}\text { Biomass } \\
\left(\mathrm{t} \mathrm{ha}^{-1}\right)\end{array}$ \\
\hline \multirow[t]{6}{*}{1} & Intercrop & CONT & $1.13^{\mathrm{c}}$ & $1502^{\text {cde }}$ & $1.17^{\mathrm{b}}$ & $2.62^{\mathrm{d}}$ & $1.33^{\text {efgh }}$ & $1836^{11}$ & $0.82^{\mathrm{b}}$ & $2.45^{\mathrm{b}}$ \\
\hline & & FYM & $1.57^{\mathrm{hi}}$ & $1595^{\text {efg }}$ & $3.44^{\mathrm{hi}}$ & $5.66^{q}$ & $1.56^{\mathrm{ij}}$ & $1888^{\mathrm{k}}$ & $3.09^{g h}$ & $5.30^{\circ}$ \\
\hline & & MRP & $1.25^{\mathrm{de}}$ & $1753^{\mathrm{hi}}$ & $2.80^{\mathrm{d}}$ & $3.72^{\mathrm{j}}$ & $1.32^{\text {efgh }}$ & $2248^{\prime}$ & $2.45^{\mathrm{d}}$ & $3.49^{i}$ \\
\hline & Monocrop & CONT & $1.16^{\mathrm{cd}}$ & $1347^{\mathrm{b}}$ & $1.27^{\mathrm{b}}$ & $2.79^{f}$ & $1.02^{\mathrm{b}}$ & $1327^{\mathrm{b}}$ & $0.93^{b}$ & $2.65^{\dagger}$ \\
\hline & & FYM & $1.52^{\mathrm{h}}$ & $1385^{\mathrm{bc}}$ & $3.66^{\mathrm{ij}}$ & $6.09^{t}$ & $1.41^{\mathrm{h}}$ & $1364^{c}$ & $3.31^{i}$ & $5.79^{t}$ \\
\hline & & MRP & $1.25^{\mathrm{e}}$ & $1650^{\text {fgh }}$ & $3.05^{\mathrm{ef}}$ & $4.18^{\prime}$ & $1.12^{\mathrm{c}}$ & $1625^{9}$ & $2.45^{\mathrm{d}}$ & $3.98^{\prime}$ \\
\hline \multirow[t]{9}{*}{ II } & Crop rotation & CONT & $1.29^{\mathrm{ef}}$ & $1575^{\text {etg }}$ & $1.57^{\mathrm{C}}$ & $2.99^{9}$ & $1.13^{\mathrm{c}}$ & $1474^{\mathrm{de}}$ & $1.22^{\mathrm{c}}$ & $2.84^{g}$ \\
\hline & & FYM & $1.68^{\mathrm{j}}$ & $1670^{g h}$ & $3.65^{\mathrm{ij}}$ & $6.13^{\mathrm{u}}$ & $1.57^{\mathrm{ijkl}}$ & $1562^{\dagger}$ & $3.30^{\mathrm{hi}}$ & $5.83^{\mathrm{u}}$ \\
\hline & & MRP & $1.39^{g}$ & $1926^{\mathrm{j}}$ & $3.22^{\text {tg }}$ & $4.32^{m}$ & $1.24^{\mathrm{de}}$ & $1802^{\text {hi }}$ & $2.87^{\dagger}$ & $4.10^{\mathrm{m}}$ \\
\hline & Intercrop & CONT & $1.24^{\text {de }}$ & $1488^{\text {cde }}$ & $1.21^{\mathrm{b}}$ & $2.58^{b}$ & $1.28^{\mathrm{efg}}$ & $1841^{\mathrm{j}}$ & $0.85^{\mathrm{b}}$ & $2.46^{\mathrm{bc}}$ \\
\hline & & FYM & $1.56^{\mathrm{hi}}$ & $1538^{\text {def }}$ & $3.56^{\mathrm{ij}}$ & $5.58^{\circ}$ & $1.67^{\mathrm{m}}$ & $1893^{k}$ & $3.18^{\mathrm{hi}}$ & $5.33^{p}$ \\
\hline & & MRP & $1.42^{\mathrm{g}}$ & $1861^{\prime \prime}$ & $2.90^{\mathrm{de}}$ & $3.67^{\prime}$ & $1.38^{\mathrm{n}}$ & $2254^{1 \mathrm{~m}}$ & $2.52^{\mathrm{de}}$ & $3.50^{\prime}$ \\
\hline & Monocrop & CONT & $1.13^{\mathrm{c}}$ & $1482^{\text {cde }}$ & $1.23^{\mathrm{b}}$ & $2.75^{\mathrm{e}}$ & $1.13^{\mathrm{c}}$ & $1321^{\mathrm{b}}$ & $0.88^{\mathrm{b}}$ & $2.61^{\mathrm{e}}$ \\
\hline & & FYM & $1.57^{\mathrm{hi}}$ & $1584^{\text {etg }}$ & $3.54^{\mathrm{hi}}$ & $6.01^{r}$ & $1.57^{\mathrm{ijk}}$ & $1365^{c}$ & $3.19^{\mathrm{hi}}$ & $5.71^{r}$ \\
\hline & & MRP & $1.25^{\mathrm{e}}$ & $1763^{\text {hi }}$ & $2.95^{\text {de }}$ & $4.13^{k}$ & $1.24^{\text {de }}$ & $1652^{\mathrm{g}}$ & $2.60^{\mathrm{de}}$ & $3.92^{k}$ \\
\hline \multirow[t]{6}{*}{ III } & Intercrop & CONT & $1.28^{\mathrm{ef}}$ & $1506^{\text {cde }}$ & $1.20^{\mathrm{b}}$ & $2.59^{b c}$ & $1.27^{\text {ef }}$ & $1827^{\mathrm{ij}}$ & $0.85^{\mathrm{b}}$ & $2.48^{d}$ \\
\hline & & FYM & $1.67^{\mathrm{j}}$ & $1599^{\text {efg }}$ & $3.53^{\mathrm{hi}}$ & $5.61^{\mathrm{p}}$ & $1.66^{\mathrm{km}}$ & $1889^{k}$ & $3.18^{\mathrm{hi}}$ & $5.37^{q}$ \\
\hline & & MRP & $1.38^{\mathrm{g}}$ & $1757^{\mathrm{ni}}$ & $2.87^{\mathrm{de}}$ & $3.69^{\prime}$ & $1.37^{\mathrm{gh}}$ & $2286^{\mathrm{mn}}$ & $2.52^{\mathrm{de}}$ & $3.53^{\prime}$ \\
\hline & Monocrop & CONT & $1.12^{\mathrm{C}}$ & $1477^{\text {cde }}$ & $1.26^{\mathrm{b}}$ & $2.77^{\mathrm{e}}$ & $1.12^{\mathrm{c}}$ & $1455^{d}$ & $0.91^{\mathrm{b}}$ & $2.63^{\mathrm{e}}$ \\
\hline & & FYM & $1.56^{\mathrm{hi}}$ & $1519^{\text {de }}$ & $3.63^{i j}$ & $6.04^{s}$ & $1.55^{\mathrm{ij}}$ & $1496^{\mathrm{e}}$ & $3.28^{\text {hi }}$ & $5.73^{s}$ \\
\hline & & MRP & $1.24^{\mathrm{de}}$ & $1809^{i j}$ & $3.02^{\operatorname{det}}$ & $4.15^{k}$ & $1.23^{\mathrm{de}}$ & $1782^{\mathrm{h}}$ & $2.42^{\mathrm{d}}$ & $3.94^{k}$ \\
\hline \multirow[t]{11}{*}{ IV } & Crop rotation & CONT & $1.29^{\text {ef }}$ & $1571^{\text {defg }}$ & $1.63^{c}$ & $3.03^{h}$ & $1.23^{\mathrm{de}}$ & $1477^{\text {de }}$ & $1.27^{\mathrm{c}}$ & $2.88^{h}$ \\
\hline & & FYM & $1.68^{\mathrm{j}}$ & $1666^{g h}$ & $3.78^{\mathrm{j}}$ & $6.22^{v}$ & $1.62^{\mathrm{jklm}}$ & $1566^{\dagger}$ & $3.39^{i}$ & $5.91^{v}$ \\
\hline & & MRP & $1.39^{9}$ & $1921^{\mathrm{j}}$ & $3.33^{g h}$ & $4.38^{n}$ & $1.35^{\text {fgh }}$ & $1807^{\mathrm{hij}}$ & $2.96^{\mathrm{fg}}$ & $4.16^{n}$ \\
\hline & Intercrop & CONT & $1.24^{\text {de }}$ & $1484^{\text {cde }}$ & $1.21^{\mathrm{b}}$ & $2.62^{\mathrm{c}}$ & $1.28^{\mathrm{efg}}$ & $1832^{\mathrm{ij}}$ & $0.86^{\mathrm{b}}$ & $2.48^{\mathrm{c}}$ \\
\hline & & FYM & $1.63^{\mathrm{ij}}$ & $1534^{\text {def }}$ & $3.56^{\mathrm{ij}}$ & $5.66^{q}$ & $1.67^{\mathrm{m}}$ & $1894^{k}$ & $3.21^{\mathrm{hi}}$ & $5.37^{q}$ \\
\hline & & MRP & $1.36^{\text {tg }}$ & $1857^{\mathrm{ij}}$ & $2.90^{\text {de }}$ & $3.72^{\mathrm{j}}$ & $1.38^{\mathrm{h}}$ & $2292^{n}$ & $2.55^{\text {de }}$ & $3.53^{\mathrm{j}}$ \\
\hline & Monocrop & CONT & $1.02^{\mathrm{b}}$ & $1352^{\mathrm{b}}$ & $1.28^{\mathrm{b}}$ & $2.79^{\dagger}$ & $1.16^{\mathrm{cd}}$ & $1448^{d}$ & $0.92^{b}$ & $2.65^{\dagger}$ \\
\hline & & FYM & $1.42^{g}$ & $1445^{\mathrm{bcd}}$ & $3.66^{\mathrm{ij}}$ & $6.09^{\mathrm{t}}$ & $1.51^{\mathrm{i}}$ & $1497^{\mathrm{e}}$ & $3.28^{\mathrm{hi}}$ & $5.79^{t}$ \\
\hline & & MRP & $1.13^{c}$ & $1608^{\text {efg }}$ & $3.05^{\text {ef }}$ & $4.18^{\prime}$ & $1.25^{\mathrm{de}}$ & $1812^{\text {hij }}$ & $2.68^{\mathrm{e}}$ & $3.98^{\prime}$ \\
\hline & & Mean & 1.134 & 1339.6 & 2.197 & 3.520 & 1.128 & 1439.2 & 1.887 & 3.344 \\
\hline & & $\mathrm{LSD}_{0.05}$ & 0.079 & 108.5 & 0.199 & 0.023 & 0.087 & 32.7 & 0.183 & 0.022 \\
\hline
\end{tabular}


These findings are similar with the results reported by [50]. Manure is a source of nutrients, which are released through mineralization, thus supplying the necessary elements for plant growth [50], and when combined with $P$ fertilizers it increases nutrient supply which enhance vegetative growth, affecting plant height and yields ([51]). Moreover, the high yields observed under manure application may be as a result of its ability for improving soil biological and physical properties which increase soil water retention and enhance nutrient uptake [52]. Applying organic fertilization (compost and animal manure) is widely found to have positive effects on crop yields. The findings are in line with those found by [53] who reported significant grain yields when FYM and $P$ fertilizers were used as compared to control treatments. This implies the possibility of replacing chemical fertilizers for organic only fertilizers in places were organic fertilizers are plenty and of high quality. This is supported by [54], that FYM could substitute $50 \%$ NPK for wheat production. As demonstrated by several long-term experiments on crop nutrition and yielding responses, the benefits of increased organic matter content will differ on the basis of the rate supplied. In a 5year trial, [55] found that every second year spreading of $40 \mathrm{t} \mathrm{ha}^{-1}$ biowaste compost, from source-separated organic household waste and yard trimmings, resulted in slightly higher $(9 \%)$ rye yields than other rates. This result suggested that beneficial use depends on choosing the best amount and frequency of compost application.

The results of this study agree with the findings of [56], who found that soils with about $100 \mathrm{tha}^{-1}$ dairy waste compost maintained $\mathrm{N}$ supply to the plants through continuous mineralization, shown by available inorganic $\mathrm{N}$ pools, silage corn yield and plant $\mathrm{N}$ content analysis. In a 7-year trial [57] confirmed that available $P$ concentration in the soil surface can contribute to corn crop $P$ uptake for more than 4 years after the last biennial $\mathrm{N}$ based compost application, being $241 \%$ higher than the control. This subject has been discussed by [19], who found that the multiple application of municipal solid waste compost associated with rock phosphate increased wheat yield by $8 \%$ compared with mineral $\mathrm{N}$ alone and induced a more productive stability and $\mathrm{N}$ uptake throughout the years.

Furthermore, maize grain yield was the highest where farmyard manure at $10 \mathrm{t} \mathrm{ha}^{-1}$ was applied along with recommended phosphate rock for 34 years, under a maize-wheat cropping system [58]. Moreover, in a 7-year study, [59] investigated vegetable-fruit-garden-waste compost combined with cattle slurry applied at both $22.5 \mathrm{t} \mathrm{ha}^{-1}$ yearly and $45 \mathrm{t} \mathrm{ha}^{-1}$ every other year. Both the application strategies resulted in 25 to $43 \%$ higher vegetable yields in respect to the two organic amendments provided alone. [60] reported that the average tomato fruit and corn grain yields, for a 5-year trial period, were 71.0 and $11.6 \mathrm{t} \mathrm{ha}^{-1}$, respectively, both not significantly different among organic, low-input and conventional farming systems.

\subsection{Maize Crop Physical Quality Attributes}

The maize cob physical quality attributes i.e. colour, shape, texture, weight, pest and disease attack and size were differently affected by cropping systems and organic inputs. Farm yard manure and Minjingu rock phosphate consistently produced maize grain with white colour, firm texture, conical shape, greater than $500 \mathrm{~g}$ and more than $20 \mathrm{~cm}$ sized cobs in all the cropping seasons in the four growing seasons at both sites as compared to control (Table 6).

Organic systems typically employ slowly released $\mathrm{N}$ sources, such as cover crop residue and manure, which may represent a slight disadvantage to nitrophilous weed species that respond quickly and efficiently to luxury $\mathrm{N}$ [61].

Nitrogen is a vitally important plant nutrient, the supply of which can be controlled by man [62]. In maize production it is a major yield-determining factor and its availability in sufficient quantity throughout the growing season is essential for optimum maize growth [63]. An adequate supply of $\mathrm{N}$ is associated with vigorous vegetative growth and a dark green colour and an imbalance of $\mathrm{N}$ or an excess of this nutrient in relation to other nutrients, such as $P, K$, and $S$ can prolong the growing period and delay crop maturity [64].

Crop quality has also been improved by manure application [65]. When crop improvements with manure were greater than those attained with commercial fertilizer, response was usually attributed to manure supplied nutrients or to 
improved soil conditions not provided by commercial fertilizer [66].

Crop rotation has been widely recommended as an effective cultural practice for increasing soil quality and crop yields in southern Brazil. Despite the emphasis given to the matter, studies on effects of crop rotation on yield are still scarce and results achieved have been contradictory [67].

Besides, the higher the organic carbon content in the soil, the higher will be the growth of plants and the addition of plant biomass provided by the CR system [67] thus contributing to enhance the microbial biomass in the soil [68] as well as its diversity [69]. This contribution allows for a higher efficiency in several key microbial processes for maximizing crop yield such as: BNF, recycling of nutrients, and suppression of disease-causing agents [70].

\subsection{Chickpea Crop Performance under Maize}

At both sites, the control treatment, no organic input, performed significantly $(p<0.05)$ lower compared to the other two treatments in chickpea under both maize and tomato rotation and intercrop. Chickpea germination, height, branches, stems, pods, biomass and grain yield increased in the different treatments in the of order control < MRP < FYM in the two cropping systems across the four growing seasons in maize at both sites (Tables 7 and 8). Observations of chickpea in rotation with maize at Kabete for season three were; control; $90.3 \%$ germination, $45 \mathrm{~cm}$ plant height, 13 branches and 2 stems, FYM: $99.3 \%$ germination, $57.5 \mathrm{~cm}$ plant height, 17 branches and 4 stems. MRP: $95 \%$ germination, $52.3 \mathrm{~cm}$ plant height, 15 branches and 4 stems. Performance of chickpea intercropped with maize in season four at the same site was; control: $79.2 \%$ germination, 36 $\mathrm{cm}$ plant height, 14 branches and 2 stems. MRP: $85.5 \%$ germination, $43.3 \mathrm{~cm}$ plant height, 16 branches and 3 stems. FYM: $95.2 \%$ germination, $48.5 \mathrm{~cm}$ plant height, 18 branches and 4 stems. The same trend was observed at Kiserian (Table 7). Full results are presented in Table 7.

\subsection{Chickpea Yield under Maize}

Chickpea in maize rotation at Kabete had: Control; $1.599 \mathrm{tha}^{-1}$ grain yield and $2.487 \mathrm{t} \mathrm{ha}^{-1}$ biomass (Table 8). FYM: $3.312 \mathrm{t} \mathrm{ha}^{-1}$ grain yield and $4.704 \mathrm{t} \mathrm{ha}^{-1}$ biomass. MRP: $2.42 \mathrm{t} \mathrm{ha}^{-1}$ grain yield and $3.341 \mathrm{t} \mathrm{ha}^{-1}$ biomass. Performance of chickpea intercropped with maize in season four at the same site was; control: $0.881 \mathrm{t} \mathrm{ha}^{-1}$ grain yields and $2.094 \mathrm{t} \mathrm{ha}^{-1}$ biomass. MRP: $1.333 \mathrm{t} \mathrm{ha}^{-}$ grain yield and $2.812 \mathrm{t} \mathrm{ha}^{-1}$ biomass. FYM: $1.824 \mathrm{t} \mathrm{ha}^{-1}$ grain yield and $4.059 \mathrm{tha}^{-1}$ biomass. The same trend was observed at Kiserian in maize (Table 8).

\subsection{Chickpea Crop Performance under Tomato}

Observations of chickpea in rotation with tomato at Kabete for season three were; control; $73.3 \%$ germination, $43 \mathrm{~cm}$ plant height, 13 branches and 1 stem, FYM: $97 \%$ germination, $55 \mathrm{~cm}$ plant height, 18 branches and 3 stems. MRP: 95\% germination, $50 \mathrm{~cm}$ plant height, 16 branches and 3 stems.

\subsection{Chickpea Yield}

Observations of chickpea yields in both rotation and intercrop with tomato at Kabete for the growing seasons showed significantly $(p<0.05)$ lower values for control as compared to the organic inputs. Chickpea in tomato rotation for season three at Kiserian performed as follows; control; $1.771 \mathrm{t} \mathrm{ha}^{-1}$ grain yield and $3.735 \mathrm{t} \mathrm{ha}^{-1}$ biomass (Table 10). FYM: $2.646 \mathrm{t} \mathrm{ha}^{-1}$ grain yield and $5.293 \mathrm{t} \mathrm{ha}^{-1}$ biomass. MRP: $2.024 \mathrm{t} \mathrm{ha}^{-1}$ grain yield and $4.1 \mathrm{t} \mathrm{ha}^{-1}$ biomass. Chickpea intercropped in tomato in season four had; control: $1.799 \mathrm{t} \mathrm{ha}^{-1}$ grain yield and $0.799 \mathrm{t} \mathrm{ha}^{-1}$ biomass. FYM: $1.433 \mathrm{tha}^{-1}$ grain yield and 2.446 $\mathrm{t}$ ha ${ }^{-1}$ biomass. MRP: $1.006 \mathrm{t} \mathrm{ha}^{-1}$ grain yield and $2.016 \mathrm{t} \mathrm{ha}^{-1}$ biomass. Full results are recorded in Table 10.

The higher number of pods weight, biomass and grain yields obtained in FYM and MRP application can be attributed to higher $\mathrm{P}$ uptake due to higher available $P$ in soil. [71] in a screen house pot experiment to assess the response of green gram (Vigna radiata L.) to application of Minjingu Mazao fertilizer $\left(31 \% \mathrm{P}_{2} \mathrm{O}_{5}\right)$ on a neutral Olasiti soil, showed that the number of pods and seeds increased from 3-6 and 7-9, respectively, in treatments 40 to $160 \mathrm{mg}$ per $4 \mathrm{~kg}$ soil of fertilizer applied. Similarly, the tissue $\mathrm{N}$ and $\mathrm{P}$ increased with treatment levels. The increase in number of pods per plant and yield signified the role of $N$ and $P$ in protein synthesis in leguminous plants like green gram. They also 
observed low responses at low $(<80 \mathrm{mg}$ per $4 \mathrm{~kg}$ soil) and high (> $320 \mathrm{mg}$ per $4 \mathrm{~kg}$ soil) rates of Minjingu Mazao fertilizer applied. The supply of $\mathrm{N}$ through biological nitrogen fixation by chickpea legume may have contributed to increased yield and yield components of chickpea. This may be due to cumulative effect by chickpea. The beneficial effect of organic waste could be attributed to the continued mineralization and release of nutrients from the organic manure.
This also could be due to the role of leguminous $\mathrm{N}$ fixing capacity of chickpea from the atmosphere. This is made available because of favourable microbial activity under rhizosphere system of leguminous crop. Additionally, it led to the enhancement of the soil nitrogen use efficiency and thus enhancing yield of maize and tomato crops as indicated in this study. This is in agreement with the findings of [51].

Table 6. Effect of season, cropping systems and organic inputs on maize physical quality attributes of maize

\begin{tabular}{|c|c|c|c|c|c|c|c|c|}
\hline Season & cs & Input & Colour & Shape & Weight (g) & $\begin{array}{l}\text { Pest \& } \\
\text { disease }\end{array}$ & Size $(\mathrm{cm})$ & Class \\
\hline \multirow[t]{6}{*}{ I } & IC & CONT & brownish & irregular & $<300$ & ++ & $<12$ & III \\
\hline & & FYM & white & conical & $>500$ & - & $>20$ & 1 \\
\hline & & MRP & white & conical & $300-600$ & +- & $12-20$ & II \\
\hline & MC & CONT & brownish & irregular & $<300$ & ++ & $<12$ & III \\
\hline & & FYM & white & conical & $>500$ & - & $>20$ & 1 \\
\hline & & MRP & white & conical & $300-600$ & - & $12-20$ & ॥ \\
\hline \multirow[t]{9}{*}{ II } & $\mathrm{CR}$ & CONT & brownish & irregular & $<300$ & ++ & $<12$ & III \\
\hline & & FYM & white & conical & $>500$ & - & $>20$ & 1 \\
\hline & & MRP & white & conical & $300-600$ & - & $12-20$ & II \\
\hline & IC & CONT & brownish & irregular & $<300$ & ++ & $<12$ & III \\
\hline & & FYM & white & conical & $>500$ & - & $>20$ & 1 \\
\hline & & MRP & white & conical & $300-600$ & - & $12-20$ & II \\
\hline & MC & CONT & brownish & irregular & $<300$ & ++ & $<12$ & III \\
\hline & & FYM & white & conical & $>500$ & - & $>20$ & 1 \\
\hline & & MRP & white & conical & $300-600$ & +- & $12-20$ & II \\
\hline \multirow[t]{6}{*}{ III } & IC & CONT & brownish & irregular & $<300$ & ++ & $<12$ & III \\
\hline & & FYM & white & conical & $>800$ & - & $>20$ & I \\
\hline & & MRP & white & conical & $500-800$ & - & $12-20$ & II \\
\hline & $\mathrm{MC}$ & CONT & brownish & irregular & $<300$ & ++ & $<12$ & III \\
\hline & & FYM & white & conical & $>800$ & - & $>20$ & 1 \\
\hline & & MRP & white & conical & $500-800$ & - & $12-20$ & II \\
\hline \multirow[t]{9}{*}{ IV } & $\mathrm{CR}$ & CONT & brownish & irregular & $<300$ & ++ & $<12$ & III \\
\hline & & FYM & white & conical & $>800$ & - & $>20$ & 1 \\
\hline & & MRP & white & conical & $500-800$ & - & $12-20$ & II \\
\hline & IC & CONT & brownish & irregular & $<300$ & ++ & $<12$ & III \\
\hline & & FYM & white & conical & $>800$ & - & $>20$ & 1 \\
\hline & & MRP & white & conical & $500-800$ & - & $12-20$ & II \\
\hline & $\mathrm{MC}$ & CONT & brownish & irregular & $<300$ & ++ & $<12$ & III \\
\hline & & FYM & white & conical & $>800$ & - & $>20$ & 1 \\
\hline & & MRP & white & conical & $500-800$ & +- & $12-20$ & II \\
\hline
\end{tabular}

Legend: CS: cropping systems, MC: monocropping, IC: intercropping, CR: crop rotation, cont: control, MRP: Minjingu rock phosphate, FYM: farm yard manure, +: presence of pest \& disease signs, -: absence of pest \& disease signs. 
Ndukhu et al.; JAERI, 12(4): 1-22, 2017; Article no.JAERI.16202

Table 7. Effects of season, cropping systems and organic inputs on yield attributes of chickpea growth in maize

\begin{tabular}{|c|c|c|c|c|c|c|c|c|c|c|}
\hline \multirow[t]{2}{*}{ Season } & \multirow{2}{*}{$\begin{array}{l}\text { Cropping } \\
\text { system }\end{array}$} & \multirow{2}{*}{$\begin{array}{l}\text { Organic } \\
\text { inputs }\end{array}$} & \multicolumn{4}{|c|}{ Kiserian } & \multicolumn{4}{|c|}{ Kabete } \\
\hline & & & $\begin{array}{l}\text { Germination } \\
(\%)\end{array}$ & $\begin{array}{l}\text { Plant height } \\
\text { (cm) }\end{array}$ & Branches & $\begin{array}{l}\text { Number } \\
\text { of stems }\end{array}$ & $\begin{array}{l}\text { Germination } \\
(\%)\end{array}$ & $\begin{array}{l}\text { Plant height } \\
\text { (cm) }\end{array}$ & Branches & $\begin{array}{l}\text { Number } \\
\text { of stems }\end{array}$ \\
\hline \multirow[t]{6}{*}{1} & Crop rotation & CONT & $93^{9}$ & $43^{\dagger}$ & $11^{\text {cd }}$ & $2^{\mathrm{C}}$ & $88^{\text {ef }}$ & $51^{\prime}$ & $13^{\text {cd }}$ & $2^{\mathrm{ef}}$ \\
\hline & & FYM & $99^{i}$ & $56^{j}$ & $14^{\mathrm{gh}}$ & $4^{i}$ & $99^{i}$ & $64^{k}$ & $17^{\text {gh }}$ & $4^{j}$ \\
\hline & & MRP & $96^{\mathrm{h}}$ & $50^{i}$ & $12^{\mathrm{ef}}$ & $3^{\text {etg }}$ & $94^{\mathrm{h}}$ & $58^{\mathrm{j}}$ & $15^{\mathrm{ef}}$ & $3^{g h}$ \\
\hline & Intercrop & CONT & $74^{\mathrm{b}}$ & $32^{\mathrm{b}}$ & $9^{b}$ & $1^{\mathrm{b}}$ & $75^{\mathrm{b}}$ & $36^{\mathrm{c}}$ & $11^{\mathrm{b}}$ & $1^{\mathrm{ab}}$ \\
\hline & & FYM & $92^{9}$ & $45^{\mathrm{g}}$ & $12^{\mathrm{ef}}$ & $3^{\text {fgh }}$ & $93^{\text {gh }}$ & $49^{h}$ & $15^{\mathrm{ef}}$ & $2^{\text {de }}$ \\
\hline & & MRP & $81^{d}$ & $39^{d}$ & $10^{\mathrm{cd}}$ & $2^{\mathrm{bcd}}$ & $82^{\mathrm{d}}$ & $43^{e}$ & $13^{\mathrm{cd}}$ & $2^{\text {cd }}$ \\
\hline \multirow[t]{3}{*}{ II } & Intercrop & CONT & $79^{\mathrm{c}}$ & $33^{\mathrm{bc}}$ & $9^{b}$ & $1^{\mathrm{b}}$ & $79^{c}$ & $34^{\mathrm{b}}$ & $11^{\mathrm{b}}$ & $1^{\mathrm{bc}}$ \\
\hline & & FYM & $97^{\mathrm{hi}}$ & $46^{g h}$ & $12^{\mathrm{et}}$ & $3^{\operatorname{tgh}}$ & $95^{\mathrm{h}}$ & $47^{g}$ & $15^{\mathrm{et}}$ & $3^{\text {gh }}$ \\
\hline & & MRP & $86^{\mathrm{e}}$ & $40^{\mathrm{de}}$ & $10^{\mathrm{cd}}$ & $2^{\operatorname{det}}$ & $86^{e}$ & $41^{d}$ & $13^{\mathrm{cd}}$ & $2^{\mathrm{et}}$ \\
\hline \multirow[t]{6}{*}{ III } & Crop rotation & CONT & $93^{9}$ & $49^{i}$ & $12^{\mathrm{de}}$ & $2^{\mathrm{bcd}}$ & $90^{\mathrm{fg}}$ & $45^{f}$ & $13^{\mathrm{cd}}$ & $2^{\mathrm{ef}}$ \\
\hline & & FYM & $99^{i}$ & $62^{k}$ & $15^{\mathrm{h}}$ & $3^{i}$ & $99^{i}$ & $58^{j}$ & $17^{g h}$ & $4^{i j}$ \\
\hline & & MRP & $96^{\mathrm{h}}$ & $56^{\prime}$ & $14^{\mathrm{tg}}$ & $3^{\operatorname{tgn}}$ & $95^{\mathrm{h}}$ & $52^{\prime}$ & $15^{\mathrm{et}}$ & $4^{\mathrm{h1}}$ \\
\hline & Intercrop & CONT & $79^{\mathrm{cd}}$ & $34^{c}$ & $10^{\mathrm{bc}}$ & $2^{b c}$ & $79^{\mathrm{c}}$ & $35^{\mathrm{bc}}$ & $12^{\mathrm{bc}}$ & $1^{\mathrm{bc}}$ \\
\hline & & FYM & $98^{\mathrm{hi}}$ & $47^{\mathrm{h}}$ & $13^{\mathrm{tg}}$ & $3^{\text {ghi }}$ & $94^{\mathrm{h}}$ & $48^{g h}$ & $16^{\text {tg }}$ & $3^{g h}$ \\
\hline & & MRP & $86^{\mathrm{e}}$ & $41^{\mathrm{e}}$ & $11^{\text {de }}$ & $2^{\text {cde }}$ & $85^{e}$ & $42^{\mathrm{de}}$ & $14^{\mathrm{de}}$ & $2^{\text {ef }}$ \\
\hline \multirow[t]{5}{*}{ IV } & Intercrop & CONT & $82^{d}$ & $34^{\mathrm{c}}$ & $11^{\mathrm{cd}}$ & $1^{\mathrm{b}}$ & $79^{\text {cd }}$ & $36^{c}$ & $14^{\mathrm{de}}$ & $2^{\text {cde }}$ \\
\hline & & FYM & $99^{i}$ & $47^{\mathrm{h}}$ & $14^{\mathrm{gh}}$ & $4^{\mathrm{hi}}$ & $95^{\mathrm{h}}$ & $49^{h}$ & $18^{\mathrm{h}}$ & $4^{\mathrm{hij}}$ \\
\hline & & MRP & $89^{\dagger}$ & $41^{\mathrm{e}}$ & $12^{\mathrm{et}}$ & $3^{\text {det }}$ & $86^{e}$ & $43^{e}$ & $16^{\dagger g}$ & $3^{\text {tg }}$ \\
\hline & & Mean & 67.4 & 33.1 & 8.8 & 1.5 & 66.3 & 34.6 & 10.3 & 1.7 \\
\hline & & $\mathrm{LSD}_{0.05}$ & 2.3 & 1.3 & 1.3 & 0.6 & 2.6 & 1.3 & 1.3 & 0.6 \\
\hline
\end{tabular}

Legend: Cont-control, MRP-Minjingu rock phosphate, FYM-farm yard manure. Means with the same letters within the column are not significantly different ( $P<0.05)$. 
Ndukhu et al.; JAERI, 12(4): 1-22, 2017; Article no.JAERI.16202

Table 8. Effects of season, cropping systems and organic inputs on yield attributes of chickpea in maize

\begin{tabular}{|c|c|c|c|c|c|c|c|c|}
\hline \multirow[t]{2}{*}{ Season } & \multirow[t]{2}{*}{ Cropping system } & \multirow[t]{2}{*}{ Organic inputs } & \multicolumn{3}{|c|}{ Kabete } & \multicolumn{3}{|c|}{ Kiserian } \\
\hline & & & Pods & $\begin{array}{l}\text { Biomass } \\
\left(\mathrm{t} \text { ha- }{ }^{-}\right)\end{array}$ & $\begin{array}{l}\text { Grain yield } \\
\left(\mathrm{t} \mathrm{ha}^{-1}\right)\end{array}$ & Pods & Biomass (t ha- ${ }^{1}$ ) & $\begin{array}{l}\text { Grain yield } \\
\left.(\mathrm{t} \mathrm{ha})^{-1}\right)\end{array}$ \\
\hline \multirow[t]{6}{*}{1} & Crop rotation & CONT & $23^{\mathrm{cde}}$ & $2.33^{\mathrm{e}}$ & $1.45^{\dagger}$ & $23^{\mathrm{cde}}$ & $1.80^{\mathrm{d}}$ & $0.60^{\mathrm{d}}$ \\
\hline & & FYM & $41^{i}$ & $4.40^{\mathrm{m}}$ & $3.01^{k}$ & $38^{\mathrm{hi}}$ & $3.69^{j}$ & $1.58^{j}$ \\
\hline & & MRP & $31^{\mathrm{fg}}$ & $3.13^{i}$ & $2.20^{i}$ & $30^{\text {fg }}$ & $2.53^{\mathrm{g}}$ & $1.07^{\mathrm{g}}$ \\
\hline & Intercrop & CONT & $15^{\mathrm{b}}$ & $1.38^{\mathrm{b}}$ & $0.57^{\mathrm{b}}$ & $14^{\mathrm{b}}$ & $1.06^{\mathrm{b}}$ & $0.26^{\mathrm{b}}$ \\
\hline & & FYM & $33^{\text {fgh }}$ & $2.60^{\mathrm{g}}$ & $1.19^{d}$ & $32^{\mathrm{fgh}}$ & $2.29^{\dagger}$ & $0.87^{\mathrm{e}}$ \\
\hline & & MRP & $23^{\text {cde }}$ & $1.85^{\mathrm{c}}$ & $0.87^{c}$ & $22^{\text {cde }}$ & $1.53^{\mathrm{c}}$ & $0.56^{\mathrm{c}}$ \\
\hline \multirow[t]{3}{*}{ II } & Intercrop & CONT & $19^{b c}$ & $2.11^{\mathrm{d}}$ & $0.87^{\mathrm{C}}$ & $18^{\mathrm{bc}}$ & $1.78^{\mathrm{d}}$ & $0.56^{\mathrm{C}}$ \\
\hline & & FYM & $37^{\text {ghi }}$ & $3.98^{\mathrm{k}}$ & $1.80^{\mathrm{h}}$ & $36^{\text {ghi }}$ & $3.65^{\mathrm{j}}$ & $1.49^{i}$ \\
\hline & & MRP & $27^{\text {det }}$ & $2.83^{\mathrm{h}}$ & $1.32^{\mathrm{e}}$ & $26^{\text {det }}$ & $2.50^{g}$ & $1.01^{\dagger}$ \\
\hline \multirow[t]{6}{*}{ III } & Crop rotation & CONT & $24^{\text {cde }}$ & $2.49^{\dagger}$ & $1.60^{\mathrm{g}}$ & $22^{\text {cde }}$ & $2.06^{\mathrm{e}}$ & $1.29^{\mathrm{h}}$ \\
\hline & & FYM & $39^{\text {hi }}$ & $4.70^{n}$ & $3.31^{\prime}$ & $40^{i}$ & $3.48^{i}$ & $3.00^{\prime}$ \\
\hline & & MRP & $31^{\text {tg }}$ & 3.34 & $2.42^{\jmath}$ & $30^{\text {tg }}$ & $2.82^{n}$ & $2.11^{\mathrm{k}}$ \\
\hline & Intercrop & CONT & $19^{\mathrm{bc}}$ & $2.12^{\mathrm{d}}$ & $0.88^{c}$ & $18^{\mathrm{bc}}$ & $1.79^{\mathrm{d}}$ & $0.57^{\mathrm{c}}$ \\
\hline & 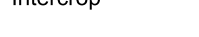 & FYM & $38^{\text {hi }}$ & $3.98^{k}$ & $1.82^{\mathrm{h}}$ & $37^{\text {hi }}$ & $3.67^{j}$ & $1.51^{i}$ \\
\hline & & MRP & $29^{\text {ef }}$ & $2.83^{h}$ & $1.33^{\mathrm{e}}$ & $28^{\text {ef }}$ & $2.51^{g}$ & $1.02^{\dagger}$ \\
\hline \multirow[t]{5}{*}{ IV } & Intercrop & CONT & $21^{\mathrm{bcd}}$ & $2.09^{d}$ & $0.88^{\mathrm{c}}$ & $20^{\mathrm{bcd}}$ & $1.79^{d}$ & $0.57^{\mathrm{c}}$ \\
\hline & & FYM & $40^{i}$ & $4.06^{1}$ & $1.82^{\mathrm{h}}$ & $39^{i}$ & $3.67^{j}$ & $1.51^{i}$ \\
\hline & & MRP & $31^{\text {tg }}$ & $2.81^{\mathrm{n}}$ & $1.33^{\mathrm{e}}$ & $30^{\text {tg }}$ & $2.52^{\mathrm{g}}$ & $1.02^{\dagger}$ \\
\hline & & Mean & 21.7 & 2.208 & 1.195 & 21.0 & 1.88 & 0.86 \\
\hline & & $\mathrm{LSD}_{0.05}$ & 6.1 & 0.057 & 0.024 & 6.1 & 0.06 & 0.02 \\
\hline
\end{tabular}


Ndukhu et al.; JAERI, 12(4): 1-22, 2017; Article no.JAERI.16202

Table 9. Effects of season, cropping systems and organic inputs on chickpea growth in tomato

\begin{tabular}{|c|c|c|c|c|c|c|c|c|c|c|}
\hline \multirow[t]{2}{*}{ Season } & \multirow{2}{*}{$\begin{array}{l}\text { Cropping } \\
\text { system }\end{array}$} & \multirow{2}{*}{$\begin{array}{l}\text { Organic } \\
\text { inputs }\end{array}$} & \multicolumn{4}{|c|}{ Kiserian } & \multicolumn{4}{|c|}{ Kabete } \\
\hline & & & $\begin{array}{l}\text { Germination } \\
(\%)\end{array}$ & $\begin{array}{l}\text { Plant height } \\
\text { (cm) }\end{array}$ & Branches & $\begin{array}{l}\text { Number of } \\
\text { stems }\end{array}$ & $\begin{array}{l}\text { Germination } \\
(\%)\end{array}$ & $\begin{array}{l}\text { Plant height } \\
\text { (cm) }\end{array}$ & Branches & $\begin{array}{l}\text { Number of } \\
\text { Stems }\end{array}$ \\
\hline \multirow[t]{6}{*}{1} & Crop & CONT & $74^{c}$ & $44^{\mathrm{d}}$ & $15^{\text {detg }}$ & $1^{b}$ & $78^{\mathrm{d}}$ & $31^{\mathrm{ef}}$ & $17^{\text {cdef }}$ & $2^{c}$ \\
\hline & rotation & FYM & $97^{\mathrm{gh}}$ & $56^{j}$ & $20^{j}$ & $4^{\dagger}$ & $100^{\mathrm{j}}$ & $33^{\mathrm{kl}}$ & $23^{\text {hi }}$ & $7^{9}$ \\
\hline & & MRP & $95^{\text {efgh }}$ & $51^{g}$ & $18^{\mathrm{hi}}$ & $2^{\mathrm{cd}}$ & $100^{\mathrm{ij}}$ & $32^{\mathrm{hi}}$ & $20^{\mathrm{g}}$ & $3^{d}$ \\
\hline & Intercrop & CONT & $72^{b}$ & $41^{\mathrm{b}}$ & $11^{\mathrm{b}}$ & $1^{b}$ & $74^{\mathrm{b}}$ & $28^{\mathrm{b}}$ & $13^{\mathrm{b}}$ & $1^{\mathrm{b}}$ \\
\hline & & FYM & $94^{\mathrm{de}}$ & $53^{h}$ & $16^{\mathrm{dfgh}}$ & $3^{\text {cde }}$ & $97^{\text {ef }}$ & $31^{\mathrm{efg}}$ & $18^{\text {def }}$ & $2^{c}$ \\
\hline & & MRP & $92^{d}$ & $48^{e}$ & $14^{\text {cde }}$ & $2^{c}$ & $96^{\mathrm{e}}$ & $30^{\mathrm{cd}}$ & $16^{\mathrm{cd}}$ & $1^{b}$ \\
\hline \multirow[t]{3}{*}{ II } & Intercrop & CONT & $73^{c}$ & $42^{\mathrm{bc}}$ & $12^{\mathrm{bc}}$ & $1^{b}$ & $76^{\mathrm{c}}$ & $29^{\mathrm{bc}}$ & $13^{b}$ & $1^{b}$ \\
\hline & & FYM & $95^{\text {etgh }}$ & $54^{\mathrm{hi}}$ & $17^{\text {gh }}$ & $3^{\text {de }}$ & $99^{\text {hij }}$ & $31^{\operatorname{tgh}}$ & $19^{\text {tg }}$ & $3^{\mathrm{de}}$ \\
\hline & & MRP & $94^{\text {et }}$ & $49^{\text {ef }}$ & $14^{\text {det }}$ & $2^{c}$ & $97^{\dagger}$ & $30^{\mathrm{de}}$ & $16^{\mathrm{cd}}$ & $2^{c}$ \\
\hline \multirow[t]{6}{*}{ III } & Crop & CONT & $94^{\text {ef }}$ & $48^{\mathrm{e}}$ & $17^{\text {gh }}$ & $3^{\text {cde }}$ & $98^{\mathrm{fghi}}$ & $32^{\text {ghi }}$ & $17^{\text {cde }}$ & $2^{c}$ \\
\hline & rotation & FYM & $96^{\text {gh }}$ & $60^{k}$ & $24^{k}$ & $5^{9}$ & $100^{\mathrm{ij}}$ & $34^{\prime}$ & $23^{i}$ & $4^{f}$ \\
\hline & & MRP & $96^{\operatorname{tgn}}$ & $55^{\jmath}$ & 20 & $3^{\text {et }}$ & $98^{\text {tghil }}$ & $33^{\mathrm{k}}$ & $20^{g h}$ & $3^{e}$ \\
\hline & Intercrop & CONT & $73^{\mathrm{bc}}$ & $42^{\mathrm{bc}}$ & $14^{\mathrm{cd}}$ & $1^{b}$ & $76^{\mathrm{bc}}$ & $30^{\mathrm{d}}$ & $13^{b}$ & $1^{\mathrm{b}}$ \\
\hline & & FYM & $96^{\operatorname{tgh}}$ & $54^{\mathrm{hi}}$ & $18^{\mathrm{hi}}$ & $3^{\text {et }}$ & $99^{\text {ghij }}$ & $32^{i j}$ & $19^{\text {tg }}$ & $3^{e}$ \\
\hline & & MRP & $94^{\text {def }}$ & $49^{\text {ef }}$ & $15^{\operatorname{detgh}}$ & $2^{c}$ & $97^{\mathrm{tg}}$ & $31^{\text {tg }}$ & $16^{\mathrm{cd}}$ & $2^{c}$ \\
\hline \multirow{5}{*}{ IV } & Intercrop & CONT & $73^{\mathrm{bc}}$ & $43^{c d}$ & $14^{\operatorname{det}}$ & $1^{b}$ & $76^{c}$ & $31^{\text {ef }}$ & $15^{\mathrm{c}}$ & $1^{b}$ \\
\hline & & FYM & $97^{\mathrm{h}}$ & $55^{\mathrm{ij}}$ & $19^{i j}$ & $3^{\text {ef }}$ & $99^{\text {hij }}$ & $33^{\mathrm{kl}}$ & $21^{\text {gh }}$ & $3^{e}$ \\
\hline & & MRP & $95^{\mathrm{etg}}$ & $50^{\text {tg }}$ & $17^{g h}$ & $3^{\text {cde }}$ & $98^{\operatorname{tgh}}$ & $32^{\mathrm{hi}}$ & $19^{\text {etg }}$ & $2^{c}$ \\
\hline & & Mean & 66.7 & 37.1 & 11.8 & 1.5 & 69.1 & 23.5 & 12.9 & 1.6 \\
\hline & & $\mathrm{LSD}_{0.05}$ & 1.5 & 1.1 & 1.8 & 0.5 & 1.4 & 0.9 & 1.9 & 0.3 \\
\hline
\end{tabular}


Table 10. Effects of season, cropping systems and organic inputs on yield attributes of chickpea in tomato

\begin{tabular}{|c|c|c|c|c|c|c|c|c|}
\hline \multirow[t]{2}{*}{ Season } & \multirow{2}{*}{$\begin{array}{l}\text { Cropping } \\
\text { system }\end{array}$} & \multirow{2}{*}{$\begin{array}{l}\text { Organic } \\
\text { inputs }\end{array}$} & \multicolumn{3}{|c|}{ Kabete } & \multicolumn{3}{|c|}{ Kiserian } \\
\hline & & & Pods & $\begin{array}{l}\text { Biomass } \\
\left.\text { (t ha- }{ }^{1}\right)\end{array}$ & $\begin{array}{l}\text { Grain yield } \\
\left(\mathrm{t} \mathrm{ha}^{-1}\right)\end{array}$ & Pods & $\begin{array}{l}\text { Biomass } \\
\left(\text { (t ha- }{ }^{1}\right)\end{array}$ & $\begin{array}{l}\text { Grain } \\
\text { yield } \\
\left(\mathrm{t} \mathrm{ha}^{-1}\right)\end{array}$ \\
\hline \multirow[t]{6}{*}{ I } & Crop & CONT & $5^{\mathrm{de}}$ & $4.0^{f}$ & $1.4^{\mathrm{e}}$ & $4^{\mathrm{de}}$ & $3.7^{f}$ & $1.8^{\mathrm{g}}$ \\
\hline & rotation & FYM & $10^{i}$ & $5.3^{\mathrm{h}}$ & $2.9^{k}$ & $9^{i}$ & $5.2^{\mathrm{g}}$ & $2.7^{i}$ \\
\hline & & MRP & $7^{\text {gh }}$ & $4.4^{\mathrm{g}}$ & $2.2^{i}$ & $7^{\text {gh }}$ & $4.1^{\mathrm{g}}$ & $1.9^{\mathrm{g}}$ \\
\hline & Intercrop & CONT & $3^{b}$ & $2.1^{\mathrm{b}}$ & $0.7^{\mathrm{b}}$ & $2^{b}$ & $1.7^{b}$ & $0.7^{\mathrm{b}}$ \\
\hline & & FYM & $7^{\mathrm{fg}}$ & $2.9^{d}$ & $1.4^{\mathrm{d}}$ & $6^{\mathrm{fg}}$ & $2.4^{\mathrm{e}}$ & $1.3^{\mathrm{e}}$ \\
\hline & & MRP & $5^{\mathrm{de}}$ & $2.5^{\mathrm{c}}$ & $1.0^{\mathrm{c}}$ & $4^{\mathrm{de}}$ & $1.9^{d}$ & $0.9^{\mathrm{d}}$ \\
\hline \multirow[t]{3}{*}{ II } & Intercrop & CONT & $3^{b c}$ & $2.0^{\mathrm{b}}$ & $1.0^{\mathrm{C}}$ & $3^{\mathrm{bc}}$ & $1.7^{\mathrm{b}}$ & $0.7^{\mathrm{bc}}$ \\
\hline & & FYM & $8^{g h}$ & $2.9^{\mathrm{de}}$ & $2.1^{\mathrm{h}}$ & $7^{\text {gh }}$ & $2.5^{\mathrm{e}}$ & $1.4^{\mathrm{ef}}$ \\
\hline & & MRP & & $2.4^{\mathrm{c}}$ & $1.5^{f}$ & $5^{\mathrm{ef}}$ & $2.0^{d}$ & $1.0^{d}$ \\
\hline \multirow[t]{6}{*}{ III } & Crop & CONT & $5^{\mathrm{de}}$ & $4.1^{f}$ & $1.9^{g}$ & $4^{\mathrm{de}}$ & $3.7^{f}$ & $1.8^{\mathrm{g}}$ \\
\hline & rotation & FYM & $10^{i}$ & $5.2^{\mathrm{h}}$ & $3.8^{\prime}$ & $9^{i}$ & $5.3^{h}$ & $2.7^{i}$ \\
\hline & & MRP & $8^{g h}$ & $4.5^{\mathrm{g}}$ & $2.8^{\mathrm{j}}$ & $7^{\text {gh }}$ & $4.1^{g}$ & $2.0^{h}$ \\
\hline & Intercrop & CONT & $4^{\mathrm{cd}}$ & $2.1^{\mathrm{b}}$ & $1.0^{\mathrm{C}}$ & $3^{\mathrm{cd}}$ & $1.7^{\mathrm{bc}}$ & $0.8^{b c}$ \\
\hline & & FYM & $9_{\mathrm{hi}}$ & $2.9^{\mathrm{de}}$ & $2.1^{\mathrm{h}}$ & $8^{\text {hi }}$ & $2.4^{\mathrm{e}}$ & $1.4^{\text {ef }}$ \\
\hline & & MRP & $7^{\mathrm{fg}}$ & $2.4^{\mathrm{C}}$ & $1.5^{f}$ & $6^{\mathrm{fg}}$ & $2.0^{d}$ & $1.0^{\mathrm{d}}$ \\
\hline \multirow[t]{5}{*}{ IV } & Intercrop & CONT & $4^{\mathrm{cd}}$ & $2.1^{\mathrm{b}}$ & $1.0^{\mathrm{C}}$ & $3^{\mathrm{cd}}$ & $1.8^{\mathrm{c}}$ & $0.8^{\mathrm{C}}$ \\
\hline & & FYM & $9^{\mathrm{hi}}$ & $3.0^{\mathrm{e}}$ & $2.1^{\mathrm{h}}$ & $8^{\text {hi }}$ & $2.5^{\mathrm{e}}$ & $1.4^{f}$ \\
\hline & & MRP & $7^{\mathrm{fg}}$ & $2.4^{\mathrm{c}}$ & $1.6^{f}$ & $6^{\mathrm{fg}}$ & $2.0^{\mathrm{d}}$ & $1.0^{d}$ \\
\hline & & Mean & 4.8 & 2.38 & 1.34 & 4.0 & 2.11 & 1.04 \\
\hline & & $\mathrm{LSD}_{0.05}$ & 1.3 & 0.09 & 0.03 & 1.3 & 0.08 & 0.11 \\
\hline
\end{tabular}

Performance of chickpea in maize and tomato rotation plots was significantly superior to those of intercrops for all attributes at both sites and in the growing seasons. The higher yield of chickpea in rotations could be attributed to higher biomass added, which in turn could have increased the nutrients content and availability over intercrops. This could also probably be due to in situ incorporation of rotated crop and its further decomposition in building organic matter content of the soil and uptake of applied nutrients by the succeeding crop leading to higher chickpea yield. This shows the higher residual effect of chickpea. Higher seed yield of chickpea in maize and tomato rotation plot could be attributed to the improvement of yield components. The data on yield attributes such as number of pods, grain yield and biomass revealed significantly higher yield attributes of chickpea recorded in rotations than intercrops. The higher dry matter production of chickpea in rotation plots may be due to differential residual effect and varied quantum of biomass incorporated under different maize and tomato. These results were in agreement with the findings of [72].

\section{CONCLUSION}

There was an increase in yields following the inputs (farm yard manure and Minjingu rock phosphate) for maize and tomato throughout the four cropping seasons in the three cropping systems. The seasonal yields were incremental while maize and tomato in chickpea rotations had the highest yields. Therefore, it is concluded that the use of farm yard manure and rock phosphate in legume integrated cropping systems contributed to relatively higher crop yields. From the current study, it can also be concluded that legume rotations and intercrops are relevant ways of enhancing food productivity as integration of chickpea enhanced maize and tomato yields.

\section{COMPETING INTERESTS}

Authors have declared that no competing interests exist.

\section{REFERENCES}

1. Swift MJ, Palm CA. Soil organic matter. An overview. In Stevenson, F.J. (Eds) 
Nitrogen in agricultural soil. Soil Use and Management. 2000;18(1):239-247.

2. Atkinson D, Watson CA. The research needs of organic agriculture, distinct or just part of agricultural research? BCPC ConferencePests and Diseases. 2000;151-158.

3. Drinkwater LE, Letourneau DK, Workneh F, Van Bruggen AHC, Shennan C. Fundamental differences between conventional and organic tomato agroecosystems in California. Ecological Applications. 1995;5:1098-1112.

4. Bouagnimbeck, Hervé. Organic farming in Africa. In: Willer, Helga und Lukas Kilcher: The World of Organic Agriculture. Statistics and Emerging Trends. IFOAM, Bonn; FiBL, Frick, ITC, Genf; 2009.

5. Reganold JP, Glover JD, Andrews PK, Hinman HR. Sustainability of three apple production systems. Nature. 2001; 410(6831):926-930.

6. Tittonell P, Vanlauwe B, Corbeels M, Giller KE. Yield gaps, nutrient use efficiencies and response fertilisers by maize across heterogeneous smallholder farms of western Kenya. Plant and Soil. 2008;313: 19-37.

7. Lal R. Food insecurity's dirty secret. Science. 2008;322:673-674.

8. Li SM, Li L, Zhang FS, Tang C. Acid phosphatase role in chickpea/maize intercropping. Annals of Botany. 2004a;94: 297-303.

9. Ghanbari A, Dahmardeh M, Siahsar BA, Ramroudi M. Effect of maize (Zea mays L.) - cowpea (Vigna unguiculata L.) intercropping on light distribution, soil temperature and soil moisture in and environment. Journal of Food, Agriculture and Environment. 2010;8:102-108.

10. Alex R. Monocrops bring food crisis. Georgia Straight; 2008.

Available: http://www.straight.com

11. Stinner B, Blair J. Ecological and agronomic characteristics of innovative cropping systems. In Edwards, C.A. Studies Centre /Centre for Urban Research. ASC Working Paper 45/2000; 1990.

12. Duflo E, Kremer M, Robinson J. How high are rates of return to fertilizer? Evidence from field experiments in Kenya; American Economic Review. 2008;98:482-488.

13. Mehlich AA, Pinkerton RW, Kempton R. Mass analysis methods for soil fertility evaluation. Internal publication, Ministry of Agriculture, Nairobi, Kenya; 1962.
14. Black CA. Methods of soil analysis. Part I and II. American Society of Agronomy. M. W.; 1965.

15. Dean JA. Flame photometry. McGraw-Hill, New York; 1960.

16. Payne RW, Murray DA, Harding SA, Baird DB, Soutar DM. GenStat for Windows, $9^{\text {th }}$ Edition. Introduction. VSN International, Hemel Hempstead; 2006.

17. Steel RGD, Torrie JH. Principles and Procedures of Statistics. A Biometrical Approach. McGraw Hill, London; 1987.

18. Erhart E, Hartl W, Putz B. Biowaste compost affects yield, nitrogen supply during the vegetation period and crop quality of agricultural crops. European Journal of Agronomy. 2005; 23:305-314.

19. Montemurro F. Different nitrogen fertilization sources, soil tillage and crop rotations in wheat: Effect on yield, quality, and nitrogen utilization. Plant Nutrition Journal. 2009;32:1-18.

20. Sisworo $W H$, Mitrusuhadjo MM, Rasjid $H$, Myers RJK. The relative roles of $\mathrm{N}$ fixation, fertilizers, crop residues and soil in supplying $\mathrm{N}$ in multiple cropping systems in a humid, tropical upland cropping system. Plant and Soil. 1990;121:73-82.

21. Rao S, Patil VS. Effect of crop residues incorporation and fertilizer application and seed yield and major nutrients uptake by safflower in semi-arid Vertisols. Karnataka Journal of Agricultural Sciences. 1990;3: 110-113.

22. Shivaram S, Radhakrishna D, Shivappa SK. Sesbania rostrata has nitrogen fixing nodules on roots as well as stems. Indian Farming. 1991;25-26.

23. Gachene CKK, Mureithi JG, Anyika F, Makau M. Incorporation of green manure cover crops in maize based cropping system in semi-arid and subhumid environments of Kenya. Legume Conference 2000, Department of Soil Science, University of Nairobi, Nairobi, Kenya. 2000;19.

24. Sunil K, Rawat CR, Melkania NP. Forage production potential and economics of maize and cowpea intercropping under rain fed condition. Indian Journal of Agronomy. 2005;50(3):184-186.

25. Mclenaghen RD, Randhawa PS, Condron, LM, Di Hong J. Increasing phosphate rock availability using a lupin green manure crop, super soil. 3rd Australian New Zealand Soil Conference, 5-9 December 
2004, University of Sydney, Australia. 2004;1-6.

26. Kathiresan G, Ayyamperumal A. Effect of green manure intercrops under different sowing methods and nitrogen level on sugarcane. Cooperative Sugar. 1996; 27:126-128.

27. Alford CM, Krall JM, Miller SD. Intercropping irrigated corn with annual legumes for fall forage in the high plains. Agronomy Journal. 2003;95:520-525.

28. Kays SJ. Preharvest factors affecting appearance. Postharvest Biology and Technology. 1999;15:233-247.

29. Clydesdale FM. Color as a factor in food choice. Critical Reviews in Food Science and Nutrition. 1993;33(1):83-101.

30. Ihl $M$, Aravena $L$, Scheuermann $E$, Uquiche E, Bifani V. Effect of immersion solutions on shelf-life of minimally processed lettuce. LWT-Food Science and Technology. 2003;36(6):591-599.

31. Shewfelt R. Quality characteristics of fruits and vegetables. In Singh, R. P. and Oliveira F. A. R. (Eds.) Minimal processing of foods and process optimization: an interface. Boca Raton, FL: CRC Press. 1994;171-189.

32. Lopez-Galvez G, Saltveit ME, Cantwell MI. The visual quality of minimally processed lettuce stored in air or controlled atmospheres with emphasis on romaine and iceberg types. Post Harvest Biology and Technology. 1996;8:179-190.

33. Bourne M. Food texture and viscosity. Food technology, International Series, (2nd Ed.). San Diego, CA: Academic Press; 2002.

34. Zhao X, Carey EE, Wang W, Rajashekar CB. Does organic production enhance phyochemical content of fruit and vegetables? Current knowledge and prospects for research. Horticultural Technology. 2006;16:449-456.

35. Chen MC. Organic fruits and vegetables: Potential health benefits and risks. Nutrition Noteworthy. 2005;7:Article 2.

36. Toor RK, Savage GP, Heeb A. Influence of different types of fertilisers on the major antioxidant components of tomatoes. Journal of Food Composition Analysis. 2006;19:20-27.

37. Dumas Y, Dadomo M, Di Lucca G, Grolier $P$. Review: Effects of environmental factors and agricultural techniques on antioxidant content of tomatoes. Journal of Science, Food and Agriculture. 2003;83:369-382.
38. Sousa C, Valentao P, Rangel J, Lopes G, Pereira JA, Ferreres F, Seabra RM, Andrade PB. Influence of two fertilization regimens on the amounts of organic acids and phenolic compounds of tronchuda cabbage (Brassica oleracea L. Variety costata D. C.). Journal of Agriculture and Food Chemistry. 2005;53: 9128-9132.

39. Young JE, Zhao X, Carey EE, Welti R, Yang S, Wang W. Phytochemical phenolics in organically grown vegetables. Molecular Nutrition and Food Research. 2005;49:1136-1142.

40. Zhao $X$, Carey EE, Young JE, Wang W, Iwamoto $T$. Influences of organic fertilization, high tunnel environment, and postharvest storage on phenolic compounds in lettuce. Horticultural Science. 2007;42:71-76.

41. Heeb A, Lundegardh B, Ericsson $\mathrm{T}$, Savage GP. Nitrogen form affects yield and taste of tomatoes. Journal of Science, Food and Agriculture. 2005;85:1405-1414.

42. Drinkwater LE, Wagoner $P$, Sarrantonio $M$. Legume-based cropping systems have reduced carbon and nitrogen losses. Nature. 1998;396:262-265.

43. Thakur BR, Singh RK, Nelson P. Quality attributes of processed tomato products: A review. Food Research International Journal. 1996;12:375-401.

44. Gennaro L, Quaglia GB. Food safety and nutritional quality of organic vegetables. In VI International Symposium on Protected Cultivation in Mild Winter Climate: Product and Process Innovation. 2002;614:675680.

45. Worthington V. Nutritional quality of organic versus conventional fruits, vegetables, and grains. Journal of Alternative and Complementary Medicine. 2001;7:161-173.

46. Lathwell DJ. Legume green manures, principles for management based on recent research. Cornell University; 1990.

47. Prasad R. Cropping system \& agricultural sustainability. Indian Farming. 1996;46:3944.

48. De R, Rao Y, Ali W. Grain and fodder legumes as preceding crops affecting yield and $\mathrm{N}$ economy in rice. Cambridge. Journal of Agricultural Sciences. 1983; 101:463-466.

49. Sogbedji JM, Van Es HM, Agbeko KL. Cover cropping and nutrient management strategies for maize production in West 
Africa. Agronomy Journal. 2006;98:883889.

50. Chiezey UF, Odunze AC. Soybean response to application of poultry manure and phosphorus fertilizer in the Sub-humid Savanna of Nigeria. Journal of Ecology and Natural Environment. 2009;1(2):025031.

51. Umoetok SBA, Uko AE, Archibong BE, Ukeh DA, Udo IA. Effect of application of inorganic fertilizer and poultry manure on insect pests and yield of soybean (Glycine max L.) in the rain forest zone of Nigeria. Journal of Food, Agriculture and Environment. 2007;5(2):149-152.

52. Nwachukwu OI, Ikeadigh MC. Water use efficiency and nutrient uptake of maize as affected by organic and inorganic fertilizer. PAT. 2012;8(1):199-208.

53. Nalatwadmath SK, Rao M, Patil SL, Jayaram NS, Bhola SN, Prasad A. Long term effects of integrated nutrient management on crop yields and soil fertility status in vertisols of Bellary. Indian Journal of Agricultural Research. 2003; 37(1):64-67.

54. Prasad B, Sinha SK. Long-term effects of fertilizers and organic manures on crop yields, nutrient balance, and soil properties in rice-wheat cropping system of Bihar. In: Abrol, I. P., Bronson, K. F., Duxbury, J. M. and Gupta, K. D. (eds), Long-term Soil Fertility Experiments in Rice-Wheat Cropping Systems. New Delhi, India: RiceWheat Consortium for the Indo-Gangetic Plains. 2000;105-119.

55. Hartl W, Putz B, Erhart E. Influence of rates and timing of biowaste compost application on rye yield and soil nitrate levels. European Journal Soil Biology. 2003;39:129-139.

56. Habteselassie MY, Miller BE, Thacker SG, Stark JM, Norton JM. Soil nitrogen and nutrient dynamics after repeated application of treated dairy-waste. Soil Science Society of America Journal. 2006a;70:1328-1337.

57. Eghball B, Ginting D, Gilley JE. Residual effects of manure and compost applications on corn production and soil properties. Agronomy Journal. 2004;96: 442-447.

58. Kaur T, Brar BS, Dhillon NS. Soil organic matter dynamics as affected by long-term use of organic and inorganic fertilizers under maize/wheat cropping system,
Nutrient Cycling in Agro-ecosystems. 2008;81:59-69.

59. Leroy BLMM, Bommele L, Reheul D, Moens M, De Neve S. The application of vegetable, fruit and garden waste (VFG) compost in addition to cattle slurry in a silage maize monoculture: Effects on soil fauna and yield. European Journal of Soil Biology. 2007;43:91-100.

60. Poudel DD, Horwath WR, Lanini WT, Temple SR, van Bruggen AHC. Comparison of soil $\mathrm{N}$ availability and leaching potential, crop yields and weeds in organic, low-input and conventional farming systems in northern California. Agronomy Ecosystems and Environment. 2002;90:125-137.

61. Altieri MA, Lana MA, Bittencourt HV, Kieling AS, Comin JJ, Lovato PE. Enhancing crop productivity in organic notill cropping systems in Santa Catarina, Brazil. Journal of Sustainable Agriculture. 2011;35:855-869.

62. Shanti KVP, Rao MR, Reddy MS, Sarma RS. Response of maize (Zea mays) hybrid and composite to different levels of nitrogen. Indian Journal of Agricultural Science. 1997;67:424-425.

63. Kogbe JOS, Adediran JA. Influence of nitrogen, phosphorus and potassium application on the yield of maize in the savanna zone of Nigeria. African Journal of Biotechnology. 2003;2(10):345-349. ISSN: $1684-5315$

64. Marti HR, Mills HA. Nutrient uptake and yield of sweet pepper as affected by stage of development and $\mathrm{N}$ form. Journal of Plant Nutrition. 1991;14(11):1165-1175.

65. Pimpini $F$, Giardini L, Borin M, Giaquinto G. Effects of poultry manure and mineral fertilizers on the quality of crops. Journal of Agricultural Science. 1992;118:215-221.

66. CAST. Integrated animal waste management. Task Force Report. No. 128. Council for Agricultural Science and Technology. Americas, lowa; 1996.

67. Zotarelli L, Zatorre N, Boddey RM, Urquiaga S, Jantalia CP, Franchini JC, Alves BJR. Influence of no-tillage and frequency of a green manure legume in crop rotations for balancing $\mathrm{N}$ outputs and preserving soil organic $\mathrm{C}$ stocks. Field Crop Research. 2012;132:185-195.

68. Dias BO, Silva CA, Higashikawa FS, Roig A, Sánchez-Monedero MA. Use of biochar as bulking agent for the composting of poultry manure: Effect on organic matter 
degradation and humification. Bioresource Technology. 2010;101(4):1239-1246.

69. Pereira AA, Hungria $M$, Franchini JC, Kaschuk G, Chueire LMDO, Campo RJ, Torres E. Qualitative and quantitative changes in soil microbiota and biological nitrogen fixation under different soybean managements. Revista Brasileira de Ciência do Solo. 2007;31(6):1397-1412.

70. Hungria M, Franchini JC, Brandão-Junior O, Kaschuk G, Souza RA. Soil microbial activity and crop sustainability in a longterm experiment with three soil-tillage and two crop-rotation systems. Applied Soil Ecology. 2009;42:288-296.

71. Kisetu E, Teveli CNM. Response of green gram (Vigna radiate L.) to an application of Minjingu Mazao fertilizer grown on Olasiti soils from Minjingu Manyara, Tanzania. Pakistan Journal of Biological Sciences. 2013;16(22):1601-1604.

72. Kler DS, Walia SS. Organic, integrated and chemical farming in wheat (Triticum aestivum) under maize (Zea mays)-wheat cropping system. Indian Journal of Agronomy. 2006;51(1):6-9.

(c) 2017 Ndukhu et al.; This is an Open Access article distributed under the terms of the Creative Commons Attribution License (http://creativecommons.org/licenses/by/4.0), which permits unrestricted use, distribution, and reproduction in any medium, provided the original work is properly cited.

Peer-review history:

The peer review history for this paper can be accessed here: http://sciencedomain.org/review-history/20837 